\title{
Instagram'da Benlik Sunumu: Takipçi Etkisi Üzerine Dramaturjik Bir İnceleme ${ }^{*}$
}

Ulkar GULMAMMADZADA, Marmara Üniversitesi, Sosyal Bilimler Enstitüsü, Bilişim Yüksek Lisans Programi, ulkeraz@hotmail.com, (D) 0000-0003-0448-7322

Şevki IŞIKLI, Marmara Üniversitesi, İletişim Fakültesi, Doç. Dr, sevki.isikli@marmara.edu.tr, 0000-0002-8075-9177

\section{$\ddot{O} Z$}

Internet tabanl iletişim teknolojileri ve özellikle sosyal medya platformları, bireysel davranışları ve toplumsal ilişkileri pek çok yönde etkiler. Sosyal medya, 21. yüzyılda ortaya çıkan dijital kültür içindeki en etkili iletişim platformdur çünkü gerçek toplumsal çevreye karşı alternatif bir sanal toplumsal çeore oluşturmaya izin verir. Kullanıcılar bu platformları sadece sosyalleşmek, diğer insanlarla bağlantı halinde olmak veya haber almak için kullanmazlar, ayn zamanda "kendilerini-benliklerini sunmak" için de kullanırlar. Kullanıcılar, sosyal medya ortamlarında kendi arzu, beğeni ve ideallerine göre yeniden inşa ettikleri bir dijital kimliğe sahip olabiliyorlar. Sosyal medyanin bu psiko-sosyal etkisinin çok yönlü olarak analiz edilmesi gerekir. Araştırmalar, "daha fazla takipçi edinme ve daha fazla izlenme arzusu"nun bazı sosyal medya fenomenlerinde kompulsif sanr aşamasına değin ilerleyebildiğini göstermektedir. Elinizdeki dramaturjik analiz araştırmasında, Instagram fenomenlerinin sosyal medyadaki benlik sunumlarn ile gözlemci-takipçi etkisi arasındaki ilişki incelenmiş; benlik sunumunda özbelikten ideal benliğe doğru geçiş şeklinde yaşanan dönüşüm, psikanalitik ve sosyal psikoloji terimleriyle yorumlanmıştır. Takipçi sayısı 10,000'den (on bin) fazla olan ve "sosyal medya fenomeni" olarak adlandirlan, rastlantısal yöntemle belirlenen 6 (altr) farklı İnstagram kullanıcısının takipçi sayısı düşük olduğ u "fenomenlik öncesi dönemi" ile takipçi sayısının 10,000'i aştı̆̆ "fenomenlik dönemi"ne ait 5'şer adet paylaşımı, Goffman'ın dramaturjik analiz yöntemiyle incelenmiştir. Bu araştırma bulgularına göre, fenomen olarak adlandırılan kullanıclar, gözlemci-takipçi etkisinin gücü ve hızına bağlı olarak beğeni odaklı benlik sunumu evresine daha hizl giriyor, öz beliklerinden daha hızl uzaklaşıyor ve gündelik benlik sunumu davranışlarını daha hizl terk ediyorlar. Bu olgu; fenomenlerin kendilerini takipçilerinin izleme, beğenme, ilgisiz kalma, cesaretlendirme, destekleme, paylaşma, kaydetme, eleştirme ve yorum yapma gibi dijital tepkilerine göre yeniden biçimlendirdikleri, benlik sunumlarnı takipçi arzularına göre yeniden şekillendiridikleri anlamına gelmektedir. Kullanıclarm bir tür dijital yabancilaşma ve öz-benlik ile ideal benlik arasındaki çatışma yaşamalar beklenilebilir. Sosyal medya bir iletişim aracı olmanın ötesine geçmiş, bir sosyal etkileşim ortamı haline gelmiştir.

\section{Anahtar : $\quad$ Takipçi Etkisi, Gözlemci Etkisi, Benlik Sunumu, Sosyal Medya, Dramaturjik Analiz, Kelimeler Instagram}

\footnotetext{
* Bu çalışma Marmara Üniversitesi Sosyal Bilimler Enstitüsü'nde 2019 yılında savunulan "Sosyal Medyada Gözlemci Etkisi ile Benlik Sunumu Arasındaki İlişki" başlıklı yüksek lisans tezi esas alınarak hazırlanmıştır.
} 


\title{
Presentation of Self in Instagram: A Dramaturgic Analysis on Observer- Follower's Effect ${ }^{*}$
}

\begin{abstract}
Internet-based communication technologies, and especially social media platforms, affect individual behaviors and social relationships in many aspects. Social media is such an effective communication platform in the digital culture emerging in the 21st century that allows to create an alternative virtual social environment to the real social environment. Users use these platforms not only to socialize, connect with other people, or receive news, but also to "present themselves-their selves." Users have a digital identity in social media environments that they construct according to their desires, likes and epitomes. This psycho-social effect of social media needs to be analyzed ambidextrously. Research shows that "the desire to gain more followers and be watched more" can progress to the stage of compulsive delusion for some social media influencers. In this dramaturgical analysis study, the relationship between the self-presentations of Instagram influencers on social media and the observer-follower effect was examined, and the transformation of self-presentation from self to the ideal self was interpreted in terms of psychoanalytic and social psychology. The number of followers of 6 (six) different Instagram users, whose number of followers is more than 10,000 and called the "social media influencer" was determined by random method. It was examined according to Goffman's dramaturgical analysis method with 5 shares belonging to the "before" and "after period" of being influencer where the number of followers exceeds 10,000. According to these research findings, users, who are called influencers, enter the like-focused self-presentation phase faster, move away from their self-characteristics faster, and abandon their daily self-presentation behaviors faster, depending on the power and speed of the observer-follower effect. This phenomenon means that influencers reshape themselves according to their followers 'digital responses such as viewing, liking, disinterest, encouraging, supporting, sharing, recording, criticizing and commenting, and reconfigure their self-presentation according to their followers' desires. Users can be expected to experience some form of digital alienation and a conflict between self and ideal self. Social media has gone beyond being a means of communication and has become a medium of social interaction.
\end{abstract}

\section{Keywords : $\quad$ Follwer's Effect, Observer Effect, Self-Presentation, Social Media, Dramaturgic} Analysis, Instagram

\section{Giriş: Toplum - Birey Etkileşimi}

Özellikle 20. yüzyılın son çeyreğinde dünya çapında dönüşüme neden olan bilişim ve iletişim teknolojilerinde gerçekleşen gelişmeler, ekranın ardındaki birer sanal “kullanıcı”ya dönüşen gerçek bireyler (Küçükvardar ve Işıklı, 2016, s.29), sosyal ağlarda benliklerini dönüştürmekte ve yeni dijital kimlikler inşa etmektedirler. Sosyal ağlardaki çeşitlenme yanında internet erişimi sağlayabilen ve yüksek miktarda görsel-işitsel veri aktarımını dokunmatik geniş ekranlarıyla olası kılan akıllı mobil teknolojiler, günümüz bireylerinin iletişimsel

\footnotetext{
* This article was prepared based on the master's thesis titled "Relationship Between Observer Effect and Self Presentation in Social Media" prepared in Marmara University Institute of Social Sciences in 2019.
} 
davranışlarını hem mobilize etmiş hem de internet ve sosyal ağlara erişimini her geçen gün ucuzlayan erişim olanakları sebebiyle kolaylaştırmıştır.

İnsanı sosyal sürüler haline yaşayan primatlar ve diğer memelilerden ayıran en önemli faktörler iletişim ve dil olgusunun yanında etrafını ve kültürünü biçimlendiren ekonomik faaliyetler sürdürmesidir. İletişim olmadan etkileşim, etkileşim olmadan da herhangi bir ilişkiden fealiyyetden söz edilemez. Sosyalleşmenin temelini teşkil eden iletişimi sağlayabilen sosyal bir insanın motivasyonu, hayat coşkusu yüksek olmakla hem ruhu ve hem de fiziksel sağlığı yerinde olur (Tonbay, 2019, s. 90). Dolayısı ile iş hayatı ve sosyal ilişkilerde başarılı olmanın temelinde yer alan iletişim bireysel ve sosyal yaşamın vazgeçilmez unsurudur.

İnsan; toplumsal, ruhsal, ekonomik, kültürel, cinsel ilişkiler içerisinde bir varlık olduğundan sürekli iç dünyası ile dış dünyası arasında bağlantılar kurar ve bu bağlantılar sayesinde kendi benliğini algılar, sorgular ve değerlendirir. Dolayısıyla bireyin benliği toplumsallaşma sürecinde iletişim sayesinde gelişmeye başlar. Toplumsallaşma sürecinde iletişim sayesinde gelişmeye başlayan bireyin benliği çevreden gelen iletiler aracılığı ile biçimlenir. Dolayısı ile iletişimin sağlanmadığ bir ortamda, benlik gelişiminden bahsedilemez (Feriha, 1989, s. 266267). Birey doğduğu andan sosyal yapının kendisine iletilen mesajları benimsemesi ile davranışlarında neyin doğru, neyin yanlış olduğunu öğrenir, davranış şekillerine yön vermekle bir kimlik sahibi olur (Özer, 1977, s. 100). Kinch'e göre benlik, kişinin sosyal bağlarıyla etkileşimleri sonucu ulaştığı tecrübelerinden gelişen ve davranışlarına yön vermesi ile kendisi hakkındaki değerlendirmelere neden olmaktadır (Kinch, 1963, s. 481).

Bilgi ve iletişim teknolojilerindeki hızlı gelişmelerle birlikte dünya çapında ortaya çıkan küreselleşme, modern toplumlardan gelen bilgi akışı ve batı kültürü insanların yaşam tarzlarını, karakter oluşturmalarını derinden etkilemeye başlamıştır (Gönenç, 1993, s. 59). Bireysel yaşam, sosyal medya araçları vasıtası ile bireyin bizzat kendisinin verdiği izin ile izlenebilir ve kayıt altına alınabilir durumuna gelmiştir. Bireyin sosyal medyada başkaları tarafından gözlemlendiğinin farkında olması, takipçileri tarafından geri bildirim alması sonucunda, davranış şekillerinde, özellikle benliğini sunumlarında ne gibi etkiler yarattığı sorusu son dönemler bilim insanlarını da düşündürmeye başlamıştır.

Yağlı'ya göre sosyal medyanın aktif kullanıcıları yaşanan günlük anılarını kaydederek her şeyi tüketim kalıpları içerisine sıkıştırmaktadırlar. Bu kullanıcılar kimlikleri, benlikleri, hayatları yeniden üretilmekte, satılmakta ve hatta bedenlerin bile yok olduğu ortam içerisindedirler (Yağlı, 2006, s. 28). Yapılan araştırmalara göre toplum içinde beğenilen, sevilen, takdir edilen biri olma isteği, bireye sosyal medya ortamında kendisini idealize ederek sunma imkânını yaratmıştır. Çevrimiçi benlik sunumları normal hayatta sunulan benlik sunumundan daha fazla içselleştirilmektedir ve sosyalleşme sürecinde bireye engel olan bazı kişisel özellikler sosyal medya uygulamaları sayesinde aradan kaldırılabilir (Bakıroğlu, 2018). 
İletişimin ve etkileşimin hızlı ve yoğun bir şekilde yaşandığı sosyal medyada kullanıcılar benlik sunumlarını ve davranışlarını gözlemci etkileriyle takipçi isteklerine, beğenilerine odaklı yapmaktadırlar. Kullanıcılar sanal dünyanın çevrimiçi sakinlerine çevrilmekle sosyal yaşamda daha aktif duruma gelmiş kendi hayatlarını başkalarının izlemesine izin vermekle üzerlerindeki gözlemci sayısını artırmıştır. Bu durumda kullanıcılar benliklerini sunarken daha çok başkalarının ideallerine uygun davranışlar sergileme eğilimlidirler. Başkalarının beğenebileceği mekânlar, markalar, yaşam tarzları, takipçilerinin beklenti ve isteklerine uygun paylaşımlar ön planda tutulmaktadır. Kullanıcıya kendi yeteneğini geliştirmekte ve çok kolay bir şekilde ün kazanmasına 1şık tutan internet ve sosyal medya beraberinde şöhret kültürü artmıştır. Sosyal medya takipçilerden gelen beğeni, yeni takipçi isteği ve yorumlar, kullanıcıların haz, güç, başarı duygusunu tatmin ederken diğer yandan da narsistik eğilimlerini artırmaktadır. Bauman'ın tabiri ile akışkan dünyanın aktif kullanıcıları, günlük anılarını hikâye bölümlerine dökerek abartılı paylaşımlar yapabilmekte, bunun sonunda bazen mutlu bazen de mutsuz olabilmektedirler.

\section{Kuramsal Çerçeve: Topluluk Önünde Benlik Sunumları}

Teknoloji ve dijitalleşen medya, zihinlerimizi, gerçekliği algılamamızı, hayat tarzımı, davranış şekillerimizi ve ritimlerimizi belirlemeye başlamış durumda. Bauman, önceki devirlerle günümüz çağını karşılaştırırken aradaki farkı "akışkan” tabiriyle anlatmaktadır. İnternete, ilişkilere mütemadi bir akışkanlık içinde bağlandığını belirten Bauman, bu durumu "bağlantıda olma", "hayatta kalma" sözleri ile açıklıyor. Haz ve hıza bağlılı̆̆ımız ilişkilerimize, davranışlarımıza, yaşam tarzımıza da yansıyor. Castells'e göre bireyler sosyal medya platformlarında benlik sunumları ile kurdukları kimlikleriyle mucizeler gerçekleştirebilme inançlarına sahiptirler (Castells, 2002, s. 213). Burada söz konusu kişinin kendi ve takipçilerinin ideallerine uygun kurgulanan benliklerin sunulmasıdır.

Goffman'a göre insanlar belirli gözlemci kümesi karşısında sundukları benliklerini, sergiledikleri performanslarını, toplumun onayladığı değerler temsilinde yapmaktadırlar. Aktör, idealize edilmiş benlik bir kere oluşturulduğunda, artık o benlikle örtüşmeyen davranışları terk etmekte ya da gizlemektedir. Goffman'a göre birey, başkalarının gözünde olumlu bir imaj yaratma çabasına girer (Goffman, 2016, s. 29). Bu durum ve sosyal medya profillerinde takipçilerin beğenisine sunulan, olumlaması beklenilen benlik sunumlarında da gözlenebilir. Dolayısıyla kullanıcılar, sosyal medyada etkileşim halinde oldukları takipçi kitlesi tarafından kabul gördüğü değerler yönünde davranış tarzı geliştirme veya rol yapma eğilimindedir. Bireyin davranışlarını anlayabilmek için benlik kavramının, Cooley'in (1962) tabiriyle benliğin ikiz kardeşi olan birey-toplum ilişkisinden daha önce, günlük yaşamdaki görünümlerinin ele alınması gerekir.

Toplum bireylerden oluşan, genel olarak ortak bir kültürü paylaşan, belli bir toprak parçasında yerleşik, kendilerini birleşik ve özgün bir varlık olarak gören insanlardan oluşan 
bir grup olarak tanımlanabilir (Marshall, 2009, s. 737). Weber' in düşüncesine göre toplumsal ilişkileri oluşturan bireyler, karşılıklı olarak davranışlarını birbirleriyle uyum sağlayarak yaparlar. Weber toplumu, bireylerin oluşturduğu sosyal ilişkileri düzenleyen ve sürekliliğ $i$ sağlayan ortak değerler sisteminin kuran bir bütün olarak tanımlamıştır (Ergun, 1973, s. 9193)

Cooley'e göre benlik ve toplum ikiz kardeşlerdir. Benlik ve toplum arasındaki organik bağlantı ve çözülmez ilişki vardır. Cooley, bir kişinin benliğinin etrafındaki çevrenin düşünceleri tarafından yani kişinin ötekilerle alışverişi yoluyla geliştirdiğini, şekillendirdiğini iddia etmiştir (Cooley, 1962, s. 5). "Herkes birbirine bir ayna yansitır ötekinin geçince karşısına" ifadesini kullanan Cooley, benliğin yansımış karakterini örneklendirme girişimi içinde onu bir aynaya benzetmiştir. Yani sahip olduğumuz yüzümüzü, görüntümüzü ve kıyafetimizi ayna karşısında görüp, bize ait olduğu için onlara ilgi duyarız. Söz konusu olduğumuz her şeyin ne gibi olmasını istiyorsak, bu isteğe nasıl bir yanıt alacağımıza göre mutlu ya da mutsuz oluruz. Aynı şekilde başka birinin zihnini de hayal gücümüzde bizim görünümümüzün, karakterimizin, yaşam tarzlarımızın, arkadaşlarımızın davranışlarımızın vb. birtakım düşünceleri olarak algılarız ve bunlar onlar tarafından çeşitli şekilde etkilenebilir (Cooley, 1962, s. 36-37).

Rogers, toplumun bir parçası olan insanın, toplumda var olabilmesi için onun kendi düşünce ve davranışların bilinçli bir şekilde yön değiştirebileceğini, ondan beklenenlere uygun davranma ve toplum tarafından kabul gören davranış tarzlarını benimseme eğiliminde olduğunu savunmaktadır (Coser, 2008, s. 70). Çağımızda bilgilerin kaydediliyor olması konuşmaları, davranışları, yorumları, tepkileri görüntüleri bir meta halinde önümüzde olduğundan bizlerden beklenen paylaşımları kontrollü şekilde yansıtmak mümkündür.

\section{Sosyal Medyada Benlik Sunumu}

Sosyal ve toplumsal yaşamda insanları başkalarına tanıtmakta yol gösteren önemli referanslardan biri de benlikleridir. Bu nedenle insanlar tüm yaşamları boyu kendi benliklerini geliştirmek için bilgi toplama çabasına girerler. Benlik kişinin iç varlığını tanıma, değerlendirme, kişinin kendi kişiliğine ilişkin düşüncelerinin bütünüdür. Kısaca birey, kişiliğinin dışarıya yansıyan, başkaları tarafından değerlendirilen yanlarını bilmeyebilir ama benlik, bireyin kendi kişiliğine ilişkin kanılarının toplamı, insanın kendisini tanıma ve değerlendirme biçimidir (Köknel, 1986, s. 78).

Yeni iletişim teknolojilerinin getirisi olarak sosyal medya modern toplumun benlikler arasındaki çatışmayı daha da etkilemektedir. Her sosyal medya hesabı, kullanıcı hakkında derinlemesine bilgi vermekte bir karakter bir kişilik taşımaktadır. Artık birey aynı zamanda sosyal medya hesaplarında oluşturduğu benliğe göre davranmakta, o benliğin sorumluluğunu da taşımaya çalışmaktadır. Çünkü modern bireyin dijital ilişkilere gösterdiği 
eğilim giderek artmaktadır. Artık sanal aracın içinde kaybolan bireyin dijital yolculuğunda kullanıcı özeni artmaktadır.

Modernite, dijitalleşme ve toplum arasındaki ilişkiyi detaylı şekilde yorumlayan Baudrillard, “Gerçek artık korunaksızdır ve onunla bir ilişkimiz kalmamıştır. Mesafelerin aradan kalktı̆̆ı bu dönemde artık simülasyon çağına girilmiştir. Bu farklı döneme geçişle artık bizler gerçeğin aktörleri değil, bir sanalın iki tarafa çalışan ajanlarıyı" der (Baudrillard, 1997, s. 125). Modern dünyada ekran karşısındaki dijital görünümünü kusursuzlaştırmanın yolu, yaşamı içinde herkesin birer aynaya dönüştügü bir tür kontrol mekanizması olarak tasarlamaktır. Kişinin daha çok göründüğü, kendisini sunduğu sosyal medya profili herkesten çok kendi bakışının daimî gözetimi altındadır. Sennett de insanların birer tiyatro oyuncusu gibi modern paylaşım sitelerinde ya da bloglarında, kendilerini izleyen seyirci kitlesine oynadığını rol yaptığını söyler (Sennett, 2012, s. 145).

Bireyin olmak istediği ama yaşayamadığı hayatı sanal ortamda yaratmak isteyen çevrimiçi dünyanın kullanıcısını Bruce Hood, profilinde yeniden benliğini keşfeden, kurgulayan ve harika bedenlere sahip, şahane mekânlarda bulunan, marka eşyalar kullanan kişiler olarak vurgular (Hood, 2014, s. 315). Kişinin, diğer insanlar ve kendisi tarafından algılanma biçimini kontrol etmesine benlik sunumu (self presentation) denilmektedir (Stefanone, 2010, s. 52). Bireyin yaşam boyunca başkalarının kendisiyle ilgili izlenimlerini, düşüncelerini önemsediği ve bu izlenimleri etkilemeye çalıştığ 1 konusuyla ilgili Baumeister, iki çeşit benlik sunumu güdüsü olduğu fikrini ortaya koymuştur: Muhatabı memnun etme güdüsü ve kendi sosyal benliğini oluşturma güdüsü. Kişinin kendisiyle ilgili olumlu şeyler düşünülmesini sağlaması, muhatabı memnun etme güdüsünde elde edilen kazançtır ve ödüllere ulaşma olasılığı yüksektir. Ancak Baumeister, sonraki yıllarda insanların bir izlenim oluşturmada gösterdiği davranışta örneğin kendini acındırarak, yücelterek etkileşimde olduğu kişiyi etkileyebileceği yönünde elde ettiği veriler sonra, bu güdüyü, muhatap karşısında oynama olarak adlandırmıştır (Baumeister, 1984, s. 13). Swann'a göre benlik sunumuna neden olan bir başka güdü daha var; insanlar var olan benlik kavramlarını kanıtlama ve böylece kendini doğrulama isteğiyle güdülenmektedir (Brehm, 1990). Sosyal medyada göz önünde olmak, fark edilmek, ilgi çekmek, beğenilmek ve değerli olmak, kişinin kendisini özel hissetmek arzusu, paylaşım yaparken fotoğrafları içerisinde onu en güzel gösteren fotoğrafını seçmeye özen gösterir ve çoğu zamanda filtre düzenlemesinden sonra takipçilerine sunar. Goffman, terminolojisinde bu sunum şeklini idealize edilen performanslar gibi değerlendiriyor (Goffman, 2016, s. 30). Sosyal medya platformlarının benliğimizi inşa etmemiz konusunda bizlere sunduğu büyük olanaklar, ideal olan ve başkaları tarafından takdir edilen benlik oluşturmamıza neden olabilmektedir. 


\section{Takipçi - Gözlemci Etkisi}

İnsanlarla çevrili bir dünyada yaşarız. Başkalarının bizimle ilgili algılarını, düşüncelerini önemseriz. Kimiyle yakın ilişkiler kurar kimine ise mesafeli davranırız. Tıpkı fiziki çevreyi kendimize göre yeniden düzenlediğimiz gibi, sosyal çevremizi de kendimiz oluşturmaya, var olanları ise yeniden biçimlendirmeye çalışırız. Bunu yapabilmek için başkalarının bizimle ilgili izlenimlerini öğrenmeye ve mümkün olduğunca bizim hakkımızda düşünmelerini istediğimiz şeyleri göstermeye çalışırız. Bu bizim doğamızın bir parçasıdır: Yaşadığımız olayları, duyguları, eylemleri başkalarıyla paylaşmak, kendimizle ilgili başkalarında olumlu izlenimler oluşturmak isteriz. Kişi, yaşamı boyunca birçok kere, kendisini tatmin edecek dışsal referanslara ihtiyaç duyar ve başkaları tarafından nasıl görüldügüne odaklanır. Bu sosyal onaya herkesin ihtiyacı vardır. Fakat sosyal onay, tek yönlü işleyemez, aksine birey-toplum etkileşimi (social interaction) denilen bir mekanizmada karşılıklık olarak alınır.

Bu noktada, mevcudiyetleri ve bakışlarıyla bize onay veya reddiyelerini hissettiren seyirciler, izleyiciler, yakın veya uzak çevremizdeki insanlar devreye girer. Hepimiz elalem denilen bir sosyal çevreniz gözetimi altındayız. Başkaları bizi orada öylece duruşlarıyla etkilerler, bakışlarıyla tedirgin ederler, telkinleriyle yönlendirirler. Bu metinde kullandığımız "gözlemci etkisi" kavramı, Kuantum mekaniğinin standart yorumunda, kuantal sistemlerin bozulmasını, onun üzerind ölçüm yapan gözlemci fizikçinin varlığı ile açıklayan çökme (collapse) postulatına gönderme yapar. Çökme postulatına göre süperpoze durumdaki bir kuantal sistem, sadece gözlem yaparak yani gözlemci etkisi ile (observer effect) gizemli biçimde çöker ve süperoze durumdan kurtularak tekil durumlara indirgenir. Gözlem yapılmadığı müddetçe de sistem süperpoze durumunu korur ve bir sonraki evreye geçemez (Işıklı, 2012, s.47). Buna göre gözlemci ile sistem, bir fizik sisteminde bile birbirini tamamlayacı unsurlardır. Buna Bohr tümlerliği denir. Benzer şekilde İnstagram fenomenleri ile onların sürekli gözetleyen takipçileri arasında bir gözlemci etkisi vardır. Bir sistem olarak kullanıcının davranışları, onu gözetleyen takipçilerinin ilgisiyle şekillenmekte, başlangıç koşullarından fenomenlik evresine kadar ulaşmaktadır. Kişisel profillerinden kendine ait paylaşımlar yapan sosyal medya kullanıcıları, takipçilerinin tepkilerine göre paylaşımlarını değiştirme yoluna giderler. Takipçilerinin beğenisine göre paylaşımlarını biçim ve içerik açısında yeniden düzenler, takiplerinin beğenmediği paylaşımları ya paylaşmazlar ya da az beğenilenleri silerler. Burada bir tür "takipçi - gözlemci etkisi” egemen olduğu görülür.

Sosyal bilimlerde, aktif haldeki bir benliğin, pasif haldeki seyirciler tarafından etki altına alındığında dair ilk ve önemli eser Goffman'ın çalışmasıdır. Goffman, izlenen ile izleyen arasındaki etkileşimi dramaturjik analiz yönteminde ayrıntılarıyla serimler. Goffman'a göre kişilerin benlik sunumu, çevresel koşullar tarafından etkilenmektedir. Goffman'ın 1959'da yazdığ 1 Günlük Yaşamda Benliğin Sunumu (The Presentation of Self in Everyday Life) isimli çalışmasında, benlik sunumu ve tarzları ayrıntılı biçimde tanımlanmıştır. Goffman, toplumsal 
dünyada rol oynayan bireyleri inceler; kişilerin, bir tiyatro sahnesinde rol yapmakta olduklarını ileri sürer. Bireyin ruhsal doğal ihtiyacı doğrultusunda kendisini sürekli başkalarına sunma hali Goffman'ın terminolojisinde "performans" olarak önümüze çıkmaktadır. Birey kendini başkalarına sunduğunda, çevresi tarafından onaylanmış değerler, inanışlar, normlar, toplum içerisinde resmi olarak kabul görmüş davranışlar doğrultusunda göstermeye başlar, yani idealize edilen performanslar sergiler (Goffman, 2016, s. 45). Yaşadığımız müddetçe devam eden gösteri, diğerleriyle ilişkilerimizle benliğimizi inşa etmemize ve sunmamiza neden olabilmektedir (Coser, 2010, s. 496). Yani aktör olan kişiler, diğerlerinden beğeni alkış almak, ötekilerin gözündeki imajını düzgün tutmak ve istediği iyi bir izlenim bırakmak amacıyla çeşitli rolleri sunmaktadırlar (Goffman, 2016, s. 22). Aynı zamanda aktör, gözlemcilerin kendisi hakkında bir izlenim oluşturmalarını ister. Kendisi hakkında yaratmak istediği sonuca gözlemcilerin varabilmesini ister. Diğer insanların kendisine tepkilerini, özellikle de kendisine nasıl davranacaklarının denetimini elinde tutmayı ister. Goffman'nın da söylediği gibi, birey kendisiyle ilgili bir izlenim oluşturduğunun farkındadır ve benlik sunumu aracılığıyla başkalarının izlenimlerini denetlemeye çalışır, bu kontrolü de durumu tanımını etkileyerek yapar.

Goffman, bireyin gözlem yoluyla kazandığı bilgilerin gözlemcilerin kendilerinden ne beklendiği ve kendilerinin karşıdakinden ne bekleyebilecekleri üzerine bir önbilgi verdiğini söyler (Goffman, 2016, s. 15). Gözlem sayesinde birey içinde bulunduğu grup ya da toplumdan onay almak, dişlanmamak için uyum göstermekte ve aynı zamanda uyum sayesinde gerekli bilgiler edinmekle sosyal kimlik kazanmak için kullanmaktadır (Tajfel, 1996). Kişinin gözlem yapması onun güvenilir bir şekilde nasıl davranmasını gerektiğini sezmesine, karşısındakinin söz ve davranışlarını yorumlamasına ışık tutar.

Kişinin günlük yaşadığı hayatın anılarını ifade edebilmesi ve benliğini sunması için mümkün görünen koşulların sonucunda bireyi kullanıcı hale getiren yeni medya ortamlarını aktifleştiren ağ toplumunda McLuhan'a göre bireysellik kültürümüzden ayrılmış insanların bir arada yaşayabileceği küresel köy haline gelmiştir. McLuhan'ın “küresel köy"ündeki insanların artık yaşanan sorunları evde sadece izlemek yerine, kendi görüş ve yorumlarını köy meydanında gündeme getirebilmektedir. Teknolojilerin yalnızca insanların kullandığı icatlar olmadığını, insanları yeniden icat eden araçlar olduğunu söyleyen McLuhan, iletişim teknolojilerinin asıl niyet ve hedefinin altını çizerek "Medya mesajdır." der (McLuhan, 1964, s. 4).

Kolay ve hızlı görünen internet alışverişlerinde veya sosyal medya kullanımında, kişiler gözetime bilinçli ya da bilinçsiz, gönüllü katkı sağlayarak katılmaktadırlar. Bu durumla kullanıcılar hayatın her alanına sızmış açı ya da gizli gözetim tekniklerinin akışkanlığını sağlayan sistemlerin gelişmesini desteklemiş hale gelirler. Sosyal medya araçlarında bilinme ve her zaman görülme arzusu, "Bir daha asla yalnız kalmama!" (Lyon, 2013, s. 31) ve "Görünüyorum, o halde varım.” (Atay, 2017) yönündeki dürtüleriyle birleşir. Bauman’ın 
belirttiği gibi, sosyal medyada fark edilme hazzl, ifşa edilme korkusundan çok daha güçlüdür. Dolayısıyla diyebiliriz ki, bireyin sosyal medyada sıklıkla görünme, takdir edilme isteği benliğini biçimlendirmesi ve sunması açısından yaptığı paylaşımlarında takipçilerinden gelen olumlu yorum ve beğeniler yönünde düzenlenmektedir. İnternet ortamında, kişiler kendi paylaşımları üzerinde daha büyük bir kontrole, gözleme sahip olmakta; açı ya da kapalı olabilecekleri gibi, sahte yüzler yaratıp gizlice olmak istedikleri kişiyi sergileyebilmektedir (Young, 2009, s. 121).

\section{Benlik Sunumuna Dair Bir Araştırma: Instagram Örneği}

Sosyal medyanın benlik sunumundaki yeri, son yıllarda yeni iletişim aracı olan Instagram'da giderek daha fazla önem kazanmış ve günlük hayatta yaygın bir şekilde yoğun olarak kullanılmaya başlanmıştır (Salomon, 2013, s. 408). Goffman'ın terminolojisinde bahsettiği tiyatro sahnesindeki aktörü izleyen seyirci yerine kullandığı gözlemci kavramı, sosyal medyaki takipçi için de genelleştirilebilir. Günlük etkileşim ve ilişkileri açıklamak için geliştirdiği rol kuramı sosyal medya platformlarında oynanabilmektedir. Bu bağlamda, bu çalışmanın teorik çerçevesini Erving Goffman'ın “Dramaturjik Modeli” ve "İzlenim Yönetimi Teorisi" oluşturmaktadır.

\subsection{Yöntemsel Çerçeve: Benlik Sunumunun Dramaturjik Analizi}

$\mathrm{Bu}$ araştırmada, sosyal medyada takipçi etkisinin (gözlemci etkisinin) kullanıcı paylaşımlarına yansıyıp yansımadığı, eğer yansıyorsa bu etkinin hangi düzeyde olduğu ve nasıl tanımlanabileceği, aynı zamanda kullanıcının benlik sunumunun takipçi etkisiyle değişip değişmediği sorularına cevap aranmaktadır. Instagram'da takipçi sayına artan kullanıcıların benlik sunum tarzları değişir; nihayetinde kullanıcılar, gerçekte olmayan fakat idealize edilmiş bir benlik sunma eğilimine girerler ve öz benliklerinden uzaklaşarak kendilerine yabancılaşırlar. Bu hipotezi test edebilmek için takipçi sayıları bir süreç içinde hızla artan, fenomen olarak tanımlanan kullanıcıların Instagram'da yaptıkları paylaşımların içerikleri analiz edilmektedir.

$\mathrm{Bu}$ çalışmanın temel amacı, kullanıcıların sosyal medya profillerinde sergiledikleri benlik sunumları ile gerçek toplumsal yaşamda sergiledikleri benlik sunumları arasındaki farkı ortaya çıkarmaktır. Bu yolla sosyal medyanın idealize edilmiş bir benlik sunumu için uygun koşullar oluşturduğu, kullanıcıları öz benliklerine yabancılaştırarak ideal benlik sunumu yapmaya zorlandıklarına dair bazı bulgulara ulaşılabileceği düşünülmektedir. Özellikle de gözlemci etkisi yaratan takipçilerin sayısındaki artış, kullanıcıların gerçekte oldukları kişi (öz benlik) ile olmak istedikleri kişi (ideal benlik) arasındaki fark, Instagram'da görünmez hale gelmektedir. 
Takipçi sayısı 10,000'den (on bin) fazla olan ve sosyal medya fenomeni olarak adlandırılan hesapları yöneten kullanıcılardan rastlantısal yöntemle belirlenen 6 (altı) kullanıcının takipçi sayısı düşük olduğu fenomenlik öncesi dönemi ile takip sayısının 10,000'i aştığ 1 fenomenlik dönemine dair 5'şer adet paylaşımı, bu form kullanılarak analiz edilmiştir. Aşağıdaki Instagram Dramaturjik İçerik Analiz Formu, Goffman'ın dramaturjik analiz tekniği temel alınarak oluşturulmuştur.

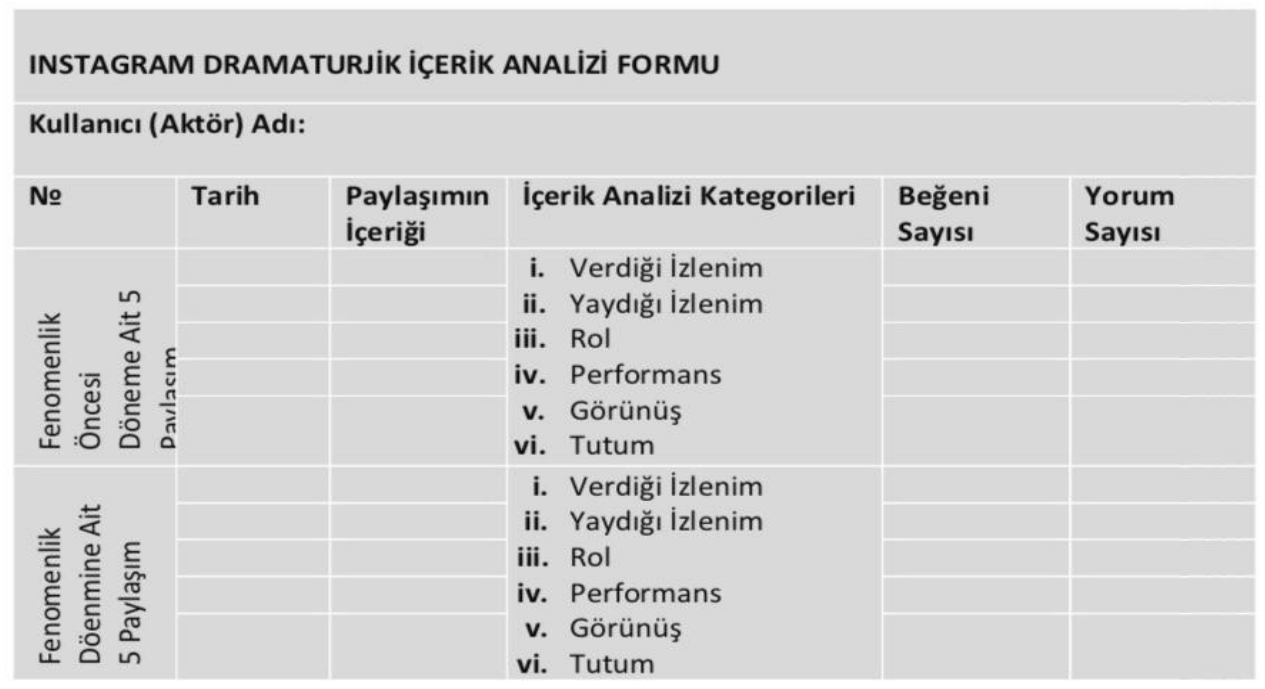

Şekil 1: Instagram Dramaturjik İçerik Analiz Formu

Dramaturjik analizde temel odak noktası, gündelik hayatta karşılaşılan durumlarda bir bireyin kendini başkalarına nasıl sunduğu, başkalarının kendisi hakkında oluşturduğu izlenimi nasıl yönlendirdiği, onların önünde performansına devam ederken neler yapabileceğ $i$ ve yapamayacağıdır (Goffman, 2016, s. 13). Goffman'ın benlik sunumu kuramında yer alan parametreler (aktör, rol/rutin, sahne önü, sahne arkası, verilen izlenim, kişisel vitrin, performans) kavramları kullanılarak yazıya geçirilmiş ve durum çalışması yapılarak (tablolar oluşturularak) değerlendirilmiştir.

Aktör/Kullanıcı: Kendisi hakkında yaratmak istediği bir sonuca gözlemcilerin varabilmesini ister. Yani diğerlerinin ona karşı olan tepkilerini, özellikle de kendisine nasıl davranacaklarının denetimini elinde tutmayı ister. Bu durumda sahte izlenimler de yaratmak istenebilir (Goffman, 2016, s. 20). Benliğin sunumunun iki şekli, yayılan ve verilen izlenim kişinin izleyicisine bıraktığı bilgi kümesidir. Sosyal medyada da kişi kendi profilini oluştururken benlik sunumunda kullandığı postlarda her iki eylem türünü de kullanabilmektedir. Kullanıcı önce vitrinini idealize ettiği şekilde kişisel bilgilerini tanımlamakta ayrıca buna uygun fotoğraflar ve videolarla düzenlenmektedir.

Performans: Goffman, bir kimsenin belli bir gözlemci kümesi önünde sürekli bulunduğu bir süre boyunca gerçekleştirdiği ve gözlemciler üzerinde biraz da olsa etkisi olan tüm faaliyetlerini anlatmak için "performans" sözcügünü kullanmaktadır. Sosyal medya 
kullanıcısının profilini takip eden bir yığın seyirci yani gözlemci kümesi, kişin paylaştığı postları, hayata geçirdiği her türlü eylemleri görebilmektedir. Goffman'a göre iki model performans vardır: Birincisi hakiki, içten veya dürüst performanslar; ikincisi ise titiz biçimde kurgulanmış, yapılandırılmış performanslardır (Goffman, 2016, s. 76).

Gözlemci/Takipçi: Sosyal medyada gözlemci olarak takipçiler ve gözlemciler diye iki kategori yapmak mümkündür. İlki kişiyi doğrudan kendi açtı̆̆ı hesap aracılığıyla takibe alan kişileri tanımlamakta, ikincisi ise takibe almadan izleyenleri tanımlamaktadır.

Rol/Rutin: Bir performans sırasında seyirciye sunulan önceden belirlenmiş ve başka durumlarda da sergilenebilecek eylem şekli rol-rutin, bu rolü gerçekleştiren kişi ise aktördür. Performansı seyreden ve bir izlenim elde eden kişi gözlemci sayılmaktadır. Aktörün yaratmak istediği etkiye hedef olan ve bu sunumdan etkilenen kişiler seyircidir (Goffman, 2016, s. 28).

Vitrin/Görünüş: Goffman kişinin performansının, gözlemcilere durumu tanımlamak için genel ve değişmez bir şekilde işleyen kısmını "vitrin" olarak tanımlamış. Ona göre, vitrin performans sırasında kişi tarafından kasıtlı ya da kasıtsız olarak kullanılan standart ifade şeklidir. Kişisel vitrin parçaları örneğin cinsiyet, boy, görünüş, duruş şekli, yüz ifadesi, vücut ifadeleri vb. (Goffman, 2016, s. 35). Vitrin sosyal medyada bireyin takipçilerine vereceği mesajın sahte, aldatıcı olarak algılanmamasını sağlamak üzere oynayacağı role ilişkin olarak profilini düzenlemesi, post ettiği görselleri ve metinleri bu çerçevede seçmesiyle oluşur.

Set/Sahne: Goffman önünde, içinde veya üzerinde sürekli sergilenen insan faaliyetlerine sahne sunan mobilya, dekor, fiziksel tasarım ve diğer arka plan düzenlemeleri set olarak tanımlar. Performanslarında belli bir seti kullanmak isteyen aktörler doğru yere gelene kadar oyunlarına başlamazlar ve orayı terk ettiklerinde de performanslarını sonlandırmak zorundadırlar (E.Goffman, 2016, s. 33). Sosyal medyada da set kişinin paylaşımına konu olan fotoğraf ve videonun nerede ve ne şekilde çekildiğidir. Bu bağlamda verilmek istenen mesaja göre set seçilmektedir. Sosyal medyada yer bildirimi yapılabilmesi de sete ilişkin bilgi paylaşımını içermektedir.

Seçilmiş 4 profil üzerinde yapılan araştırmadan her bir profil sahibinin istatistik verileri, (hedef kitlesi, takipçileri yaş aralığı, cinsiyet oranı) zaman içindeki etkileşim oranı (beğeni sayısı + yorum sayısı) eski postlarla güncel postlar arasındaki fark, paylaşım sıklığı, paylaşım tarzı (mekân, dekolte, eşya, vb.) arasındaki ilişkiler analiz edildi. Kişinin zamanla takipçi sayısının yükselmesi ve etkileşim oranının artması nedeniyle benlik sunumundaki farkları ilk 5 ve güncel son 5 paylaşımı üzerinde incelendi ve tablolar oluşturularak Goffman'ın terminolojisi kapsamında değerlendirildi. Bunu yapmaktaki amaç kullanıcının sosyal medya platformu Instagram'a ilk katıldığı dönemlerde yaptığı paylaşımları ile güncel paylaşımlarını karşılaştırmak ve davranışlarının hangi yönde değiştiğini belirlemektir. 
Instagram'da Benlik Sunumu: Takipçi Etkisi Üzerine Dramaturjik Bir İnceleme Ulkar GULMAMMADZADA, Şevki IŞIKLI 


\subsection{Instagram Fenomenlerinin Profillerinin Dramaturjik Analizleri}

\subsubsection{Kullanıcı D'nin analizi}

32 yaşındaki Kullanıcı D, cast direktörlügü (filmler için oyuncu seçimi yöneticiliği) yaparken Instagram' da paylaşım yapmaya başladı. 2014 yılında açtığı hesabında mesleğine ait sanatsal fotoğraf paylaşmış fakat zaman içinde yaptığı videoların çok etkileşim aldığını fark edince paylaşımlarının içerik ve türlerini değiştirmiştir. Şu anda 20 binin üzerinde takipçisi olan bir sosyal medya fenomenidir.

Tablo 1: Kullanıcı D’ye Ait Instagram Profili İstatistiksel Verileri
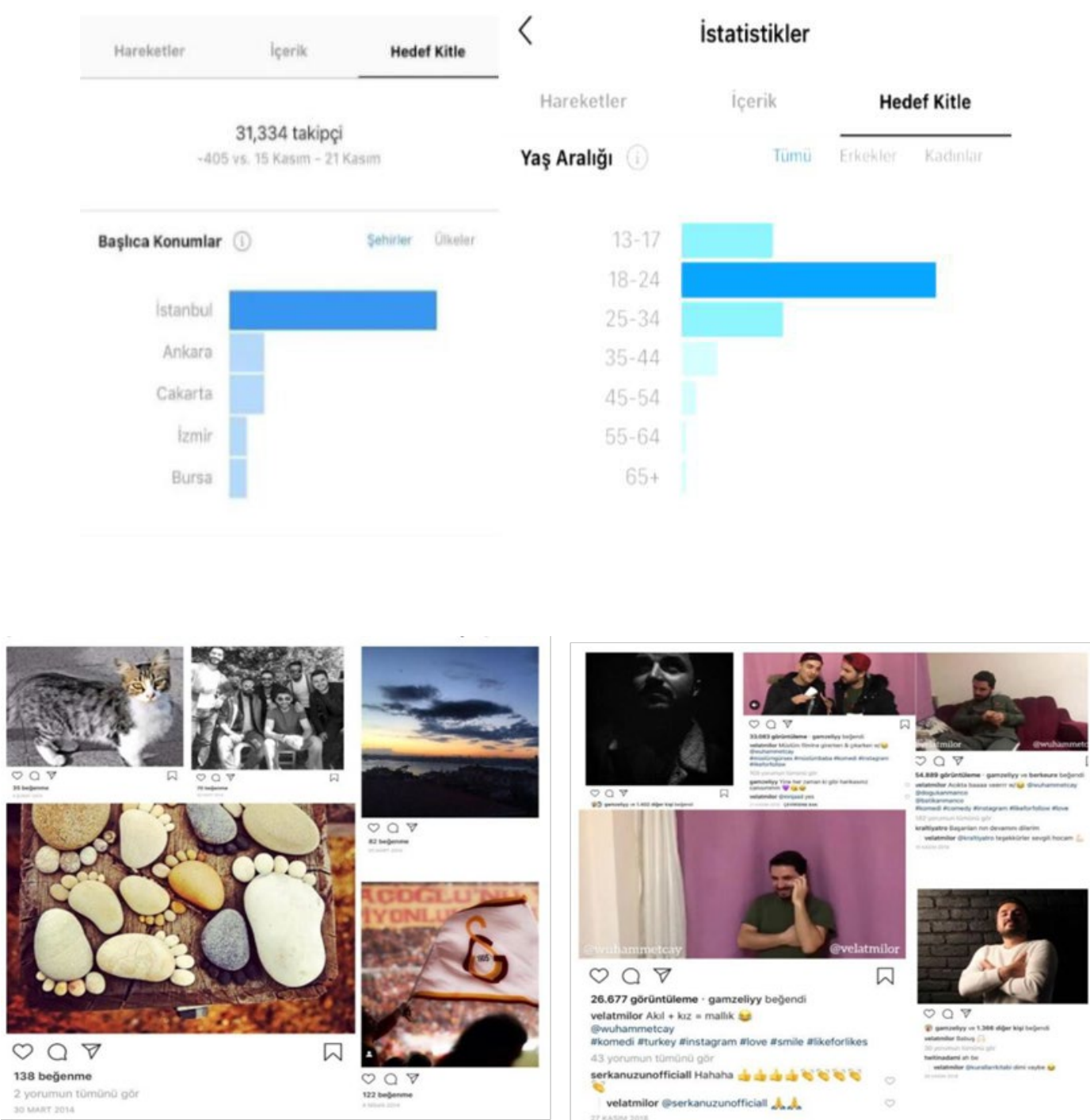

Görsel 1: D Kullanıcısının Fenomenlik Öncesi ve Sonraki Döneme Ait 5 Paylaşımı 
Tablo 2: Kullanıı D’nin Fenomenlik Öncesi Döneme ve Fenomenlik Dönemine Ait Paylaşımlarının Dramaturjik Analizi

\begin{tabular}{|c|c|c|c|c|c|}
\hline \multicolumn{6}{|c|}{ INSTAGRAM DRAMATURJIK IÇERIK ANALIZ FORMU } \\
\hline \multicolumn{6}{|c|}{ Kullanıcı (Aktör) Adı: D Kullanıcısı } \\
\hline № & Tarih & $\begin{array}{l}\text { Paylaşımın } \\
\text { İçeriği }\end{array}$ & İçerik Analizi Kategorileri & $\begin{array}{l}\text { Beğeni } \\
\text { Sayısı }\end{array}$ & $\begin{array}{l}\text { Yoru } \\
\text { m } \\
\text { Sayısı }\end{array}$ \\
\hline \multirow{5}{*}{ 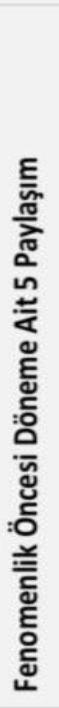 } & $\begin{array}{l}4 \text { Şubat } \\
2014\end{array}$ & $\begin{array}{l}\text { Dış mekan: } \\
\text { Sokak Kedisi }\end{array}$ & \multirow{5}{*}{$\begin{array}{l}\text { Verdiği İzlenim: Maç sahası, doğa } \\
\text { ve sanatsal fotoğraflar, } \\
\text { arkadaşlarla toplu çekim } \\
\text { Yaydığı İzlenim: Arkadaş canlısı } \\
\text { hayvanları ve sanatı seven, } \\
\text { Galatasaray takımlı. } \\
\text { Rol: Kişi kendisini doğayı, sanatı, } \\
\text { hayvanları seven Galatasaray } \\
\text { takımlı biri olarak tanımlamış. } \\
\text { Performans: } 5 \text { fotoğraf } \\
\text { paylaşımında toplam } 400 \text { beğeni, } \\
4 \text { yorum almıştır. } \\
\text { Kişisel vitrin/Görünüş: Orta } \\
\text { boylu, esmer, sempatik. } \\
\text { Tutum: Hayvanlara ilgi } \\
\text { duymaktadır. Doğayı ve maça } \\
\text { gitmeyi seviyor. Yorum yapmadan } \\
\text { paylaşımda bulunarak fikir } \\
\text { bildirmemeyi tercih etmiş. }\end{array}$} & 35 & - \\
\hline & $\begin{array}{l}22 \text { Mart } \\
2014\end{array}$ & $\begin{array}{l}\text { Grup } \\
\text { fotoğrafı: } \\
\text { Arkadaşlarıyla }\end{array}$ & & 70 & - \\
\hline & $\begin{array}{l}23 \text { Mart } \\
2014\end{array}$ & $\begin{array}{l}\text { Manzara: } \\
\text { Bulut ve deniz }\end{array}$ & & 85 & 4 \\
\hline & $\begin{array}{l}25 \text { Mart } \\
2014\end{array}$ & $\begin{array}{l}\text { Taş süslemesi } \\
\text { (sanatsal) }\end{array}$ & & 82 & - \\
\hline & $\begin{array}{l}30 \text { Mart } \\
2014\end{array}$ & $\begin{array}{l}\text { Galatasaray } \\
\text { Maç Sahası }\end{array}$ & & 128 & - \\
\hline \multirow{5}{*}{ 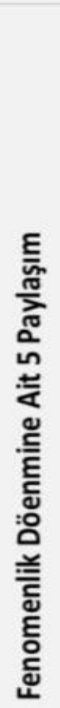 } & $\begin{array}{l}15 \text { Kasım } \\
2018\end{array}$ & Video: Vine & \multirow{5}{*}{$\begin{array}{l}\text { Verdiği İzlenim: Komedi } \\
\text { fenomeni } \\
\text { Yaydığı İzlenim: Oyuncu, } \\
\text { tanınmış kişi. } \\
\text { Rol: Kişi kendisini komedyen } \\
\text { oyuncu olarak göstermektedir. } \\
\text { Performans: } 2 \text { fotoğraf ve } 3 \text { vine } \\
\text { video paylaşımın sonucunda } \\
\text { 113,189 beğeni, } 364 \text { yorum } \\
\text { almıştır. } \\
\text { Kişisel vitrin/Görünüş: Orta } \\
\text { boylarında esmer, bakımlı, pozitif. } \\
\text { Tutum: Kendi yeteneklerini } \\
\text { sergileyen video vinelar } \\
\text { oluşturarak insanları güldürmeyi } \\
\text { amaçlamaktadır. Takipçi kitlesinin } \\
\text { takipte kalmasını ve yeni takipçi } \\
\text { kazanmayı hedeflemektedir. }\end{array}$} & 54.704 & 182 \\
\hline & $\begin{array}{l}19 \text { Kasım } \\
2018\end{array}$ & $\begin{array}{l}\text { Profesyonel } \\
\text { çekim: Siyah } \\
\text { beyaz çekilmiş } \\
\text { kişisel fotoğraf }\end{array}$ & & 1.403 & - \\
\hline & $\begin{array}{l}21 \text { Kasım } \\
2018\end{array}$ & $\begin{array}{l}\text { Video: Vine, } \\
\text { komedi }\end{array}$ & & 33.058 & 109 \\
\hline & $\begin{array}{l}27 \text { Kasım } \\
2018\end{array}$ & $\begin{array}{l}\text { Video: Vine, } \\
\text { komedi }\end{array}$ & & 22.658 & 43 \\
\hline & $\begin{array}{l}28 \text { Kasım } \\
2018\end{array}$ & $\begin{array}{l}\text { Profesyonel } \\
\text { çekim: Kişisel } \\
\text { fotoğraf }\end{array}$ & & 1.366 & 30 \\
\hline
\end{tabular}

Verdiği İzlenimin Karşılaştırılması: D Kullanıcısının fenomenlik öncesi dönem ile fenomenlik dönemi arasındaki benlik sunumu farklılaşması oldukça barizdir. Takipçi sayısı ve paylaşımların aldığı etkileşimler arttıkça bu fark artmıştır. Fenomenlik öncesi dönemde daha çok genel fotoğraflar, fenomenlik döneminde ise daha çok video, vine, komedi tarzı içerikler paylaşmaktadir.

Yaydığı İzlenimin Karşılaştırılması: Fenomenlik öncesi dönemde hayvanlara ve sanata ilgi duyan ve arkadaşlarıyla vakit geçirmeyi seven biri izlenim verirken fenomenlik döneminde özellikle vine videoları paylaşarak daha fazla kişi tarafından ilgi gören, beğenilen, yeteneklerini geliştirerek popüler olan biri izlenimini vermektedir. Rol Karşılaştırması: D kullanıcının rolü 
sıradan birey olmaktan çıarak fenomen oyunculuk yönüne doğru değişim göstermiştir. Fenomen olduktan sonra paylaşımlarını özenle düzenlemektedir.

Performans Karşılaştırması: Yukarıdaki tablodan da açık şekilde görmekteyiz ki D kullanıcı ilk paylaşılan 5 fotoğrafından toplam 400 beğeni, 4 yorum almıştır. Fakat D kişisinin fenomen olduktan sonra performans gösterisi son güncel 2 fotoğraf ve 3 vine video paylaşımın sonucunda 113,189 beğeni, 364 yorum alarak yükselmiştir.

Kişisel vitrin / Görünüm Karşılaştırması: D kişisi önceleri fotoğraf paylaşırken yorum yapmamayı tercih ederken güncel paylaşımlarında insanları güldürmek ve onları kazanmak amaçlı yeteneklerini sergilemekten çekinmemektedir. Önceleri genel paylaşımlara ağrılık vermesiyle kendini ön planda tutmak istememiştir. Fakat son paylaşımlarında daha bakımlı görünüş, profesyonel makineyle kurgulu çekilen içeriklere üstünlük vermiştir.

\subsubsection{Kullanıcı Ç'nin Analizi}

Tablo 3: Kullanıcı Ç'ye Ait Instagram Profili İstatistiksel Verileri
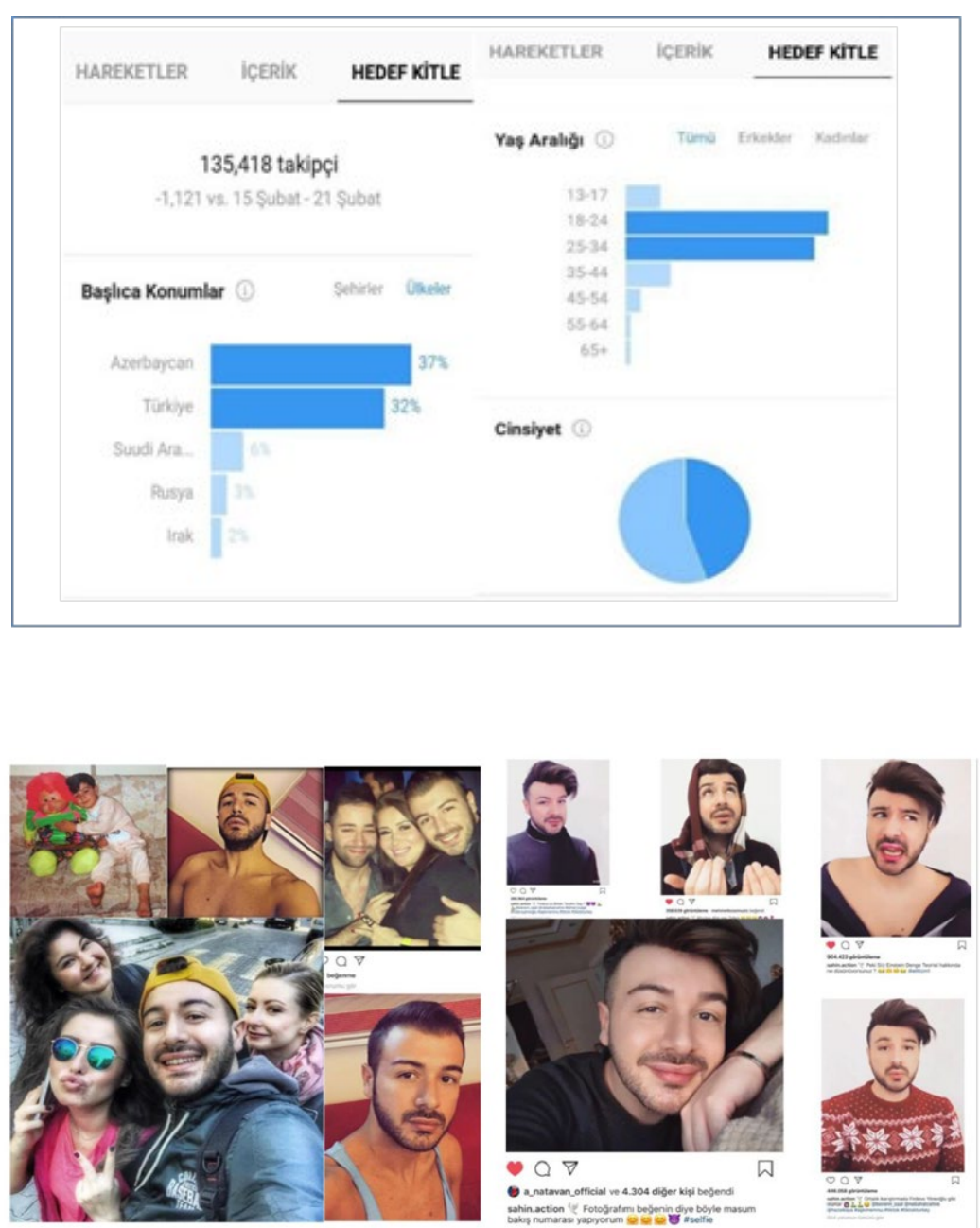

Görsel 2: Kullanıcı Ç'nin Fenomenlik Öncesi ve Sonraki Döneme Ait 5 Paylaşımı 
Tablo 4: Kullanıcı Ç'nin Fenomenlik Öncesi Döneme ve Fenomenlik Dönemine Ait Paylaşımlarının Dramaturjik Analizi

\begin{tabular}{|c|c|c|c|c|c|}
\hline \multicolumn{6}{|c|}{ INSTAGRAM DRAMATURJIK IÇERIK ANALiz FORMU } \\
\hline \multicolumn{6}{|c|}{ Kullanıcı (Aktör) Adı: Ç Kullanıcısı } \\
\hline № & Tarih & $\begin{array}{l}\text { Fotoğraf } \\
\text { Içeriği }\end{array}$ & İçerik Analizi Kategorileri & $\begin{array}{l}\text { Beğeni } \\
\text { Sayısı }\end{array}$ & $\begin{array}{l}\text { Yorum } \\
\text { Sayısı }\end{array}$ \\
\hline \multirow{5}{*}{ 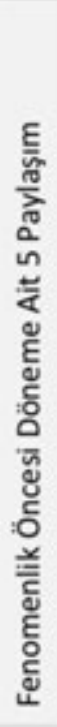 } & $\begin{array}{l}14 \text { ağustos } \\
2014\end{array}$ & $\begin{array}{l}\text { Kişisel fotoğraf: } \\
\text { Çocukluk } \\
\text { fotoğrafı }\end{array}$ & \multirow{5}{*}{$\begin{array}{l}\text { Verdiği İzlenim: Kūçüklük anısı, vūcut } \\
\text { yapısı, kişisel ve arkadaşlarla fotoğraflar. } \\
\text { Yaydığı İlenim: Genç, kendisini seven, } \\
\text { arkadaş canlısı, sık sık özçekim yapan biri. } \\
\text { Rol: Kişi kendisini ve arkadaşlarını çok } \\
\text { seven biri olarak tanımlamış. } \\
\text { Performans: } 5 \text { fotoğraf paylaşımında } \\
\text { toplam } 410 \text { beğeni, } 0 \text { yorum almıştır. } \\
\text { Kişisel vitrin/Görünūş: Orta boylu, sarışın, } \\
\text { sempatik. } \\
\text { Tutum: Dudaklarını büzerek poz } \\
\text { vermesinden seksi görünmeye çalışan ve } \\
\text { aynı şekilde bedenini sergileme arzusunda } \\
\text { olan biri. Bu durum narsist duyguların } \\
\text { tatmini şeklinde değerlendirilebilir. } \\
\text { Görünme ve görüntüsū ile insanlanı } \\
\text { etkileme çabası içindedir. }\end{array}$} & 159 & - \\
\hline & $\begin{array}{l}15 \text { ağustos } \\
2014\end{array}$ & $\begin{array}{l}\text { İç mekan: Evde } \\
\text { yan çıplak yaka } \\
\text { ön planlı fotoğraf }\end{array}$ & & 85 & - \\
\hline & $\begin{array}{l}17 \text { ağustos } \\
2014\end{array}$ & $\begin{array}{l}\text { Dış mekan: } \\
\text { Arkadaşlarıyla } \\
\text { birlikte çekim }\end{array}$ & & 42 & - \\
\hline & $\begin{array}{l}18 \text { ağustos } \\
2014\end{array}$ & $\begin{array}{l}\text { Dış mekan: } \\
\text { Arkadaşı ile } \\
\text { birlikte öz çekim }\end{array}$ & & 53 & - \\
\hline & $\begin{array}{l}19 \text { ağustos } \\
2014\end{array}$ & $\begin{array}{l}\text { İç mekan: Evde, } \\
\text { dudaklar ön } \\
\text { planda ōzçekim }\end{array}$ & & 71 & - \\
\hline \multirow{5}{*}{ 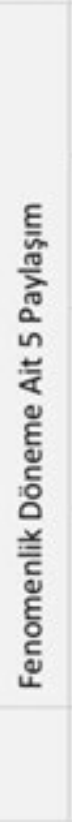 } & $\begin{array}{l}1 \text { Mart } \\
2019\end{array}$ & $\begin{array}{l}\text { Video: Bir dizini } \\
\text { sahnesi üzerine } \\
\text { sesli canlandırma, } \\
\text { vine. }\end{array}$ & \multirow{5}{*}{ 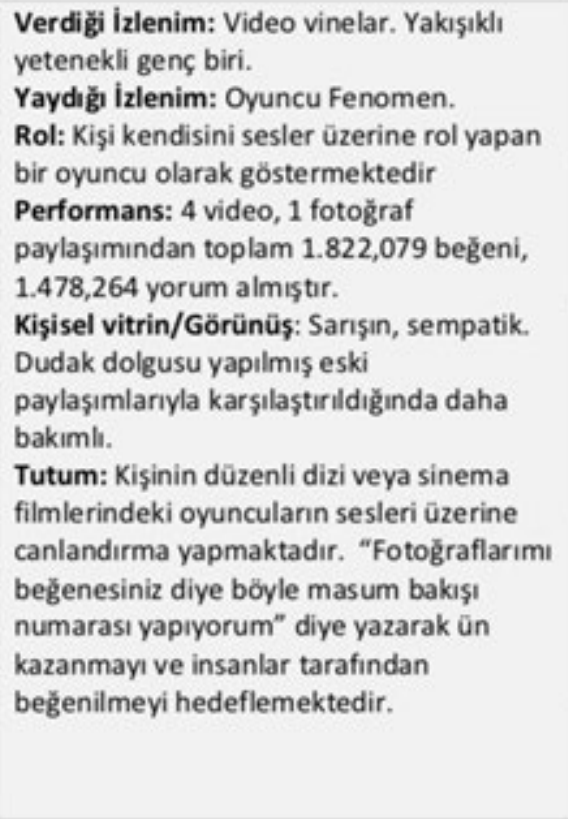 } & 252.426 & 192 \\
\hline & $\begin{array}{l}3 \text { Mart } \\
2019\end{array}$ & $\begin{array}{l}\text { Video: Bir dizini } \\
\text { sahnesi üzerine } \\
\text { sesli canlandırma, } \\
\text { vine. }\end{array}$ & & 327.488 & 447 \\
\hline & $\begin{array}{l}4 \text { Mart } \\
2019\end{array}$ & $\begin{array}{l}\text { Video: Bir tv } \\
\text { programındaki bir } \\
\text { sahne ūzerine bir } \\
\text { canlandırma }\end{array}$ & & 833.286 & 1.264 \\
\hline & $\begin{array}{l}5 \text { Mart } \\
2019\end{array}$ & $\begin{array}{l}\text { Video: Bir tv } \\
\text { dizisinin } \\
\text { karakterlerini } \\
\text { taklit eden vine }\end{array}$ & & 404.737 & 637 \\
\hline & $\begin{array}{l}6 \text { Mart } \\
2019\end{array}$ & $\begin{array}{l}\text { İç mekan: Evde, } \\
\text { koltuk üzerinde } \\
\text { özçekim }\end{array}$ & & 4.142 & 201 \\
\hline
\end{tabular}

Verdiği İzlenimin Karşılaştırılması: Ç fenomeni, sıradan bir kullanıcı olduğu dönemlerde genellikle kişisel fotoğraflarını paylaşmakla vücut yapısını, dudaklarını sergileyecek öz çekimlere üstünlük vermiş. Aynı zamanda arkadaşlarıyla toplu fotoğraf çekimlerinin paylaşımında bulunmuş. Fakat fenomene çevrildikten sonra paylaşımlarının \% $090^{\prime}$ ını film ve dizilerden karakterlerin sesleri ile canlandırdığı videolar kapsamaktadır. 
Yaydı̆̆g İzlenimlerin Karşılaştırılması: İlk başlarda genç sempatik öz çekim yapmayı seven sıradan biri olarak izlenim yaysa da takipçi ve yorum sayısı yükseldikçe daha profesyonel şekilde rol yapıp kurguladığı video çekimlerinden oyuncu izlenimini yaymaktadır. Aynı zamanda takipçi, yorum sayısı ve video izlenim sayılarından başkaları tarafından ilgi gören, sevilen, ünlü fenomen izlemini bırakmaktadır.

Rollerin Karşılaştırılması: Sıradan kullanıcıyken arkadaşlarıyla zaman geçiren kendisini seven biri olarak görünse de fenomen olduktan sonra sürekli kendi üzerinde yeteneklerini geliştiren yeni canlandırmalar için çalışan çeşitli roller yapan oyuncu olarak görünmektedir.

Performansların Karşılaştırılması: Ç kişisinin ilk 5 fotoğrafı, toplam 410 beğeni, 0 yorum almıştır. Fenomen olduktan sonraki 5 paylaşımı ise toplam 1,822,079 beğeni, 1,478,264 yorum almıştır.

Kişisel Vitrinin / Görünüşün Karşılaştırılması: Ç kişisinin ilk paylaşımları ile son paylaşımları karşılaştırıldığında, estetik operasyon geçirdiği, dudak dolgusu yaptırdı $\breve{g ̆}_{1}$ belli olmaktadır. Son paylaşımlarında kişisel görünümüne yatırım yaptığı açıkça görülmektedir. İlk paylaşımlarında kendi kişisel fotoğraflarını paylaşmakla yetinirken son paylaşımlarında yeteneklerini ön plana çıkarttı̆̆ı anlaşılmaktadır. 


\subsubsection{Kullanıcı E'nin Analizi}

35 yaşındaki erkek E kullanıcısı, 2014'ten beri Instagram kullanmaktadır. Bekar olduğu ilk dönemlere ait kişisel fotoğraflarını, evlendikten sonra silmiştir. Şuanda aile, iş, gezi ve tatil fotoğrafları paylaşan, 51 bin takipçisi olan bir Instagram fenomenidir.

Tablo 5: E Kullanıcısına Ait Instagram Profili İstatistiksel Verileri

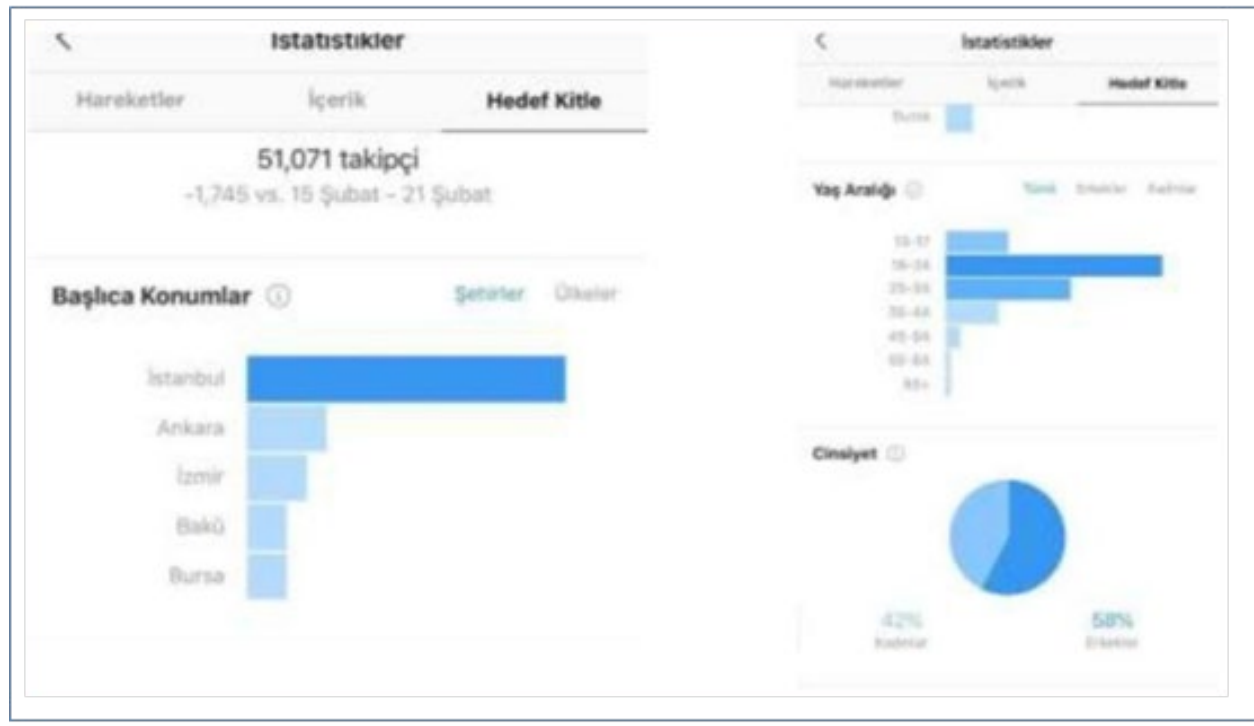

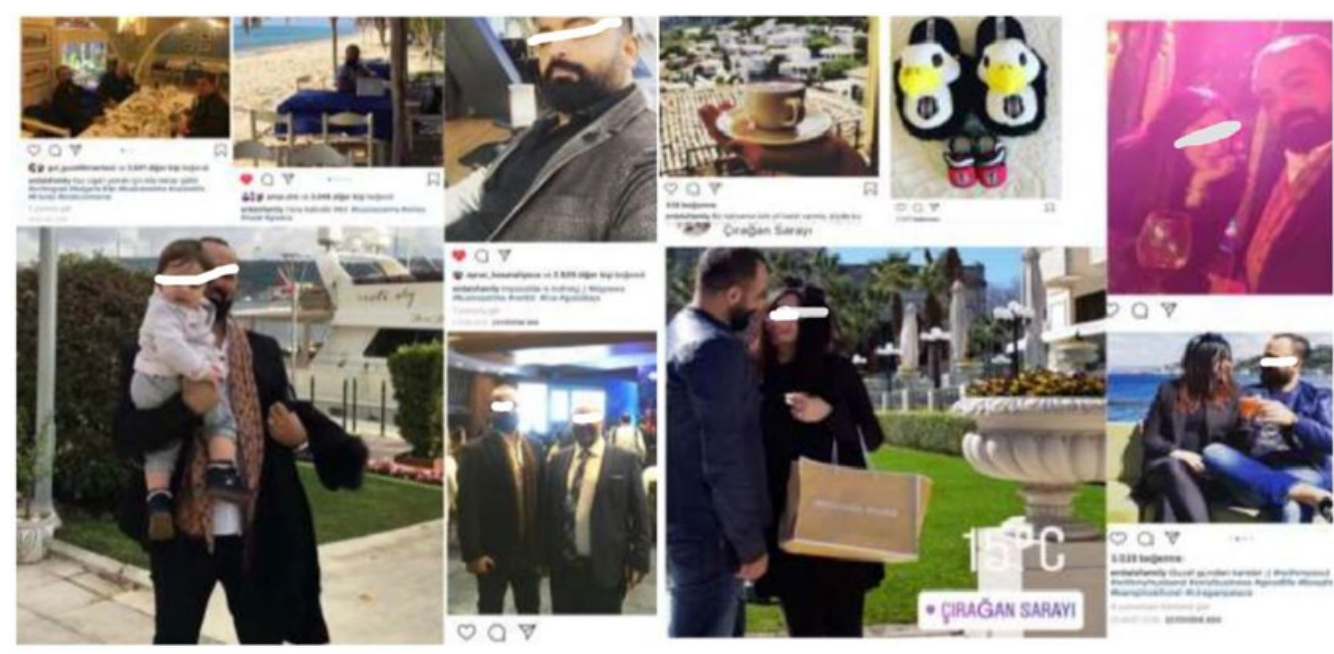

Görsel 3: Kullanıcı E'nin Fenomenlik Öncesi ve Sonraki Döneme Ait 5 Paylaşımı 
Tablo 6: Kullanıcı E'nin Fenomenlik Öncesi Döneme ve Fenomenlik Dönemine Ait Paylaşımlarının Dramaturjik Analizi

\begin{tabular}{|c|c|c|c|c|c|}
\hline \multicolumn{6}{|c|}{ INSTAGRAM DRAMATURJIKK IÇERIK ANALIZ FORMU } \\
\hline \multicolumn{6}{|c|}{ Kullanıcı (Aktör) Adı: E Kullanıcısı } \\
\hline № & Tarih & $\begin{array}{l}\text { Fotoğraf } \\
\text { Içeriği }\end{array}$ & Içerik Analizi & $\begin{array}{l}\text { Beğeni } \\
\text { Sayısı }\end{array}$ & $\begin{array}{l}\text { Yorum } \\
\text { Sayısı }\end{array}$ \\
\hline \multirow{5}{*}{ 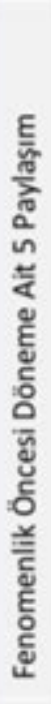 } & $\begin{array}{l}9 \text { Eylül } \\
2017\end{array}$ & $\begin{array}{l}\text { Manzara ōnūnde } \\
\text { kahve fotoğrafı }\end{array}$ & $\begin{array}{l}\text { Verdiği İzlenim: Aile fotoğraflan, kahve } \\
\text { fotoğrafı. } \\
\text { Yaydığı i̇lenim: Evli, gezmeyi, kahve ve } \\
\text { içkiyi seven, Beșiktaş takımlı biri. }\end{array}$ & 340 & $\cdot$ \\
\hline & $\begin{array}{l}17 \text { Ekim } \\
2017\end{array}$ & $\begin{array}{l}\text { Beşiktaş takımlı } \\
\text { terlik }\end{array}$ & $\begin{array}{l}\text { Rol: Kişi eși ile beraber fotoğraflarını daha } \\
\text { fazla paylaşmakla iyi bir eş rolünde } \\
\text { kendisini sunmaktadır. }\end{array}$ & 1.778 & 4 \\
\hline & $\begin{array}{l}8 \text { Kasım } \\
2017\end{array}$ & $\begin{array}{l}\text { Eși ve kendisi içki } \\
\text { masasında }\end{array}$ & $\begin{array}{l}\text { Performans: } 5 \text { fotoğraf paylașımında } \\
\text { toplam } 11.799 \text { beğeni, } 18 \text { yorum almıştır. } \\
\text { Kişisel vitrin: } \\
\text { Görünüş: Esmer, az sakallı, orta boylu, }\end{array}$ & 2.780 & 7 \\
\hline & $\begin{array}{l}20 \text { Mart } \\
2018\end{array}$ & $\begin{array}{l}\text { Çıră̆an sarayında } \\
\text { eșiyle beraber } \\
\text { elinde marka } \\
\text { poșet }\end{array}$ & $\begin{array}{l}\text { marka kıyafetler giyinmeye üstünlük } \\
\text { vermektedir. } \\
\text { Tutum: Eşiyle beraber fotoğrafları altına } \\
\text { bıraktığı 'Benim ruhum benim eşim' gibi }\end{array}$ & 3.375 & 3 \\
\hline & $\begin{array}{l}23 \text { Mart } \\
2018\end{array}$ & $\begin{array}{l}\text { Eşi ile beraber dış } \\
\text { çekim }\end{array}$ & $\begin{array}{l}\text { mesajları ve kalp emojileriyle eșini çok } \\
\text { sevdiğini belirtmektedir. }\end{array}$ & 3.526 & 4 \\
\hline \multirow{5}{*}{ 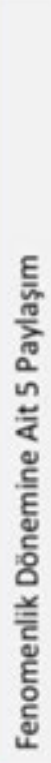 } & $\begin{array}{l}26 \text { Eylül } \\
2018\end{array}$ & $\begin{array}{l}\text { Balık ve içki } \\
\text { masası arkasında } \\
\text { arkadaşlarla toplu } \\
\text { fotoğraf }\end{array}$ & $\begin{array}{l}\text { Verdiği İlenim: Tatil, iş ve arkadaşlarla } \\
\text { fotoğraf, aile videosu. } \\
\text { Yaydığı İzlenim: İş adamı, arkadaşlarını } \\
\text { seven, evli, erkek çocuk babası. }\end{array}$ & 3.041 & 1 \\
\hline & $\begin{array}{l}2 \text { Ekim } \\
2018\end{array}$ & $\begin{array}{l}\text { Önünde Apple } \\
\text { laptop, deniz } \\
\text { manzaralı tatil } \\
\text { fotoğrafı. }\end{array}$ & $\begin{array}{l}\text { Rol: Kişi kendisini çok çalışan iş adamı, iyi } \\
\text { bir baba, eş olarak tanımlanmaktadır. } \\
\text { Performans: } 4 \text { fotoğraf ve } 1 \text { video } \\
\text { paylaşımından toplam } 21,691,24 \text { yorum }\end{array}$ & 3.046 & 2 \\
\hline & $\begin{array}{l}5 \text { Ekim } \\
2018\end{array}$ & $\begin{array}{l}\text { Hava alanında } \\
\text { özçekim. }\end{array}$ & $\begin{array}{l}\text { almıştır. } \\
\text { Kişisel vitrin: }\end{array}$ & 2.931 & 1 \\
\hline & $\begin{array}{l}11 \\
\text { Kasım } \\
2018\end{array}$ & $\begin{array}{l}\text { Çocuğu ve eși ile } \\
\text { beraber } \\
\text { Ortaköy'de } \\
\text { tekneye binerken } \\
\text { video }\end{array}$ & $\begin{array}{l}\text { Görünūș: Esmer, sakallı, orta boylu, marka } \\
\text { kıyafetler giyinmeye üstünlük vermektedir. } \\
\text { Tutum: Fotoğrafları altına bıraktığı } \\
\text { 'business time', 'en büyūk servetim canım } \\
\text { ailem' gibi mesajlarıyla kendi işinde başarılı }\end{array}$ & 2.658 & 16 \\
\hline & $\begin{array}{l}22 \\
\text { Kasım } \\
2018\end{array}$ & $\begin{array}{l}\text { İstanbul Ticaret } \\
\text { Odasında iş } \\
\text { arkadașı ile } \\
\text { fotoğraf }\end{array}$ & $\begin{array}{l}\text { mutlu bir aileye sahip biri olarak hava } \\
\text { atmayı amaçlamaktadır. }\end{array}$ & 10.015 & 4 \\
\hline
\end{tabular}

Karşılaştırılması Verdiği İzlenimin Karşılaştırılması: E kullanıcısı, Instagram'ı ilk kullanmaya başladığ1 dönemlerde paylaştı̆̆ 1 fotoğraflarda kendisini beğenmediği için ve o fotoğrafları yeni takipçilerinin görmesini istemediği için silmiştir. 2017 ile güncel postlarında verdiği izlenimler arasında pek fark görülmemiştir. E kullanıcısı, genellikle aile ve arkadaş ortamında ünlü güzel mekânlarda çekilen fotoğraf ve videolar paylaşmıştır. 
Yaydığı İzlenimin Karşılaştırılması: Önceleri genellikle eşi ile beraber tatil fotoğraflarıyla ailesi olduğu izleniminde bulunan E kişisi, son güncel paylaşımlarında aileli, bir çocuk babası, mutlu bir iş adamı izlenimini yayacak fotoğraflara ağırlık vermiş.

Rollerin Karşılaştırılması: E kullanıcısı 2017 senesindeki paylaşımlarında kendisini ailesine bağlı, eşini çok seven rolündedir. Güncel paylaşımlarda ise kendisini artık bir çocuk babası ve hep çalışan mutlu iş adamı olarak tanımlamaktadır. Performans Karşılaştırması: 2017 senesinde paylaşılan 5 fotoğraftan toplam 11.799 beğeni, 18 yorum almıştır. Son güncel 4 fotoğraf ve 1 video paylaşımından toplam 21,691, 24 yorum almakla performans göstericisi yükselmiştir.

Kişisel Vitrinin / Görünüşün Karşılaştırılması: E kullanıcısın 2017 ile son güncel paylaşımlarındaki görünüşünde pek fark bulunmamaktadır. Fakat güncel paylaşımlarında ailesi ile olsa da sürekli çalışan iş adamı olduğunu belli etmek istemiştir. Aynı zamanda mutlu bir aileye sahip olmakla gezi, tatil fotoğraflarıyla hava atmaya eğilimlidir. 


\subsubsection{Kullanıcı I'nın Analizi}

39 yaşındaki erkek I kullanıcısı, oyuncu ve sunucu olarak çalışmaktadır. 2013 yılından beri Instagram kullanmaktadır. Şu anda kişisel, iş ve reklam türü paylaşımları yapan 102 bin takipçisi olan bir Instagram fenomenidir.

Tablo 7: Kullanıcı I'nın Ait Instagram Profili İstatistiksel Verileri

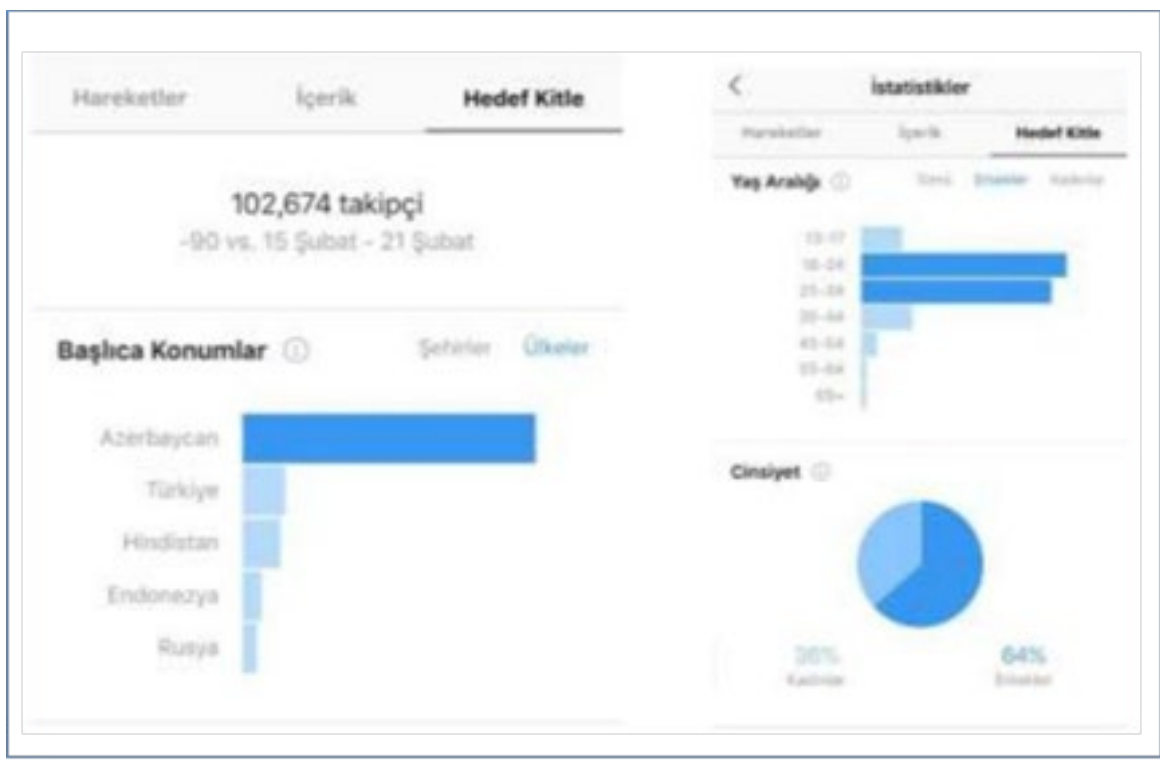

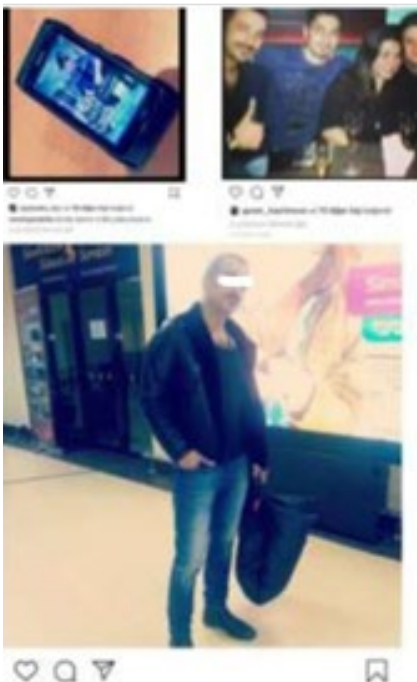

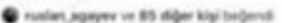
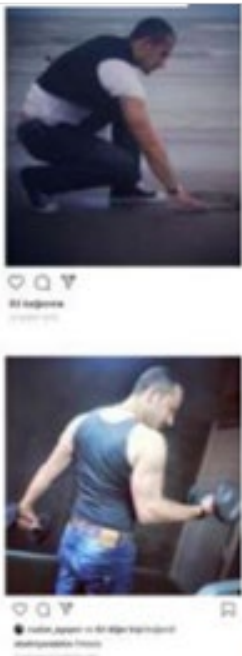

$a$
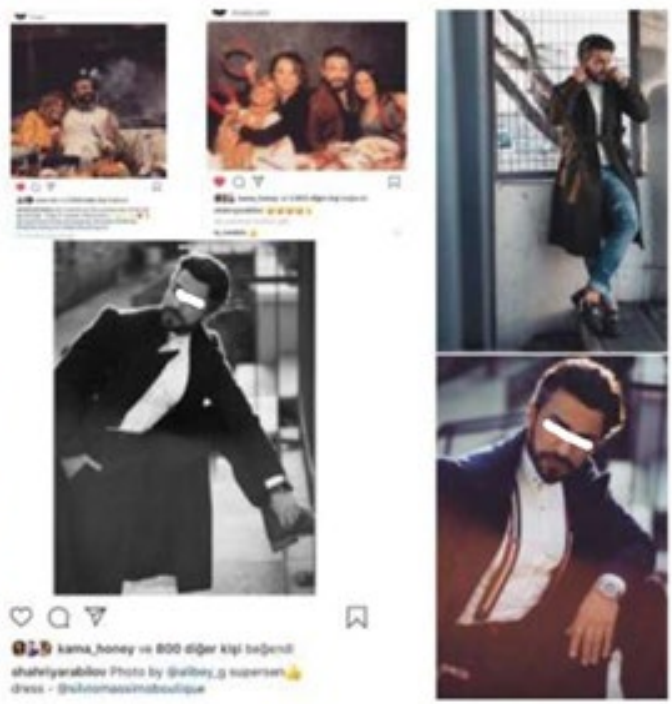

Görsel 4: Kullanıcı I'nın Fenomenlik Öncesi ve Sonrakı Döneme Ait 5 Paylaşımı 
Tablo 8: Kullanıı I'nın Fenomenlik Öncesi Döneme ve Fenomenlik Dönemine Ait Paylaşımlarının Dramaturjik Analizi

\begin{tabular}{|c|c|c|c|c|c|}
\hline \multicolumn{6}{|c|}{ INSTAGRAM DRAMATURJIK IÇERIK ANALIZ FORMU } \\
\hline \multicolumn{6}{|c|}{ Kullanıcı (Aktör) Adı: I Kullanıcısı } \\
\hline № & Tarih & $\begin{array}{l}\text { Fotoğraf } \\
\text { Iç̧eriĕíl }\end{array}$ & İçerik Analizi & $\begin{array}{l}\text { Beğeni } \\
\text { Sayısı }\end{array}$ & $\begin{array}{l}\text { Yorum } \\
\text { Sayısı }\end{array}$ \\
\hline \multirow{5}{*}{ 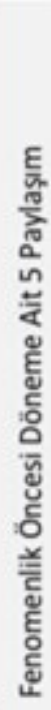 } & $\begin{array}{l}22 \\
\text { Şubat } \\
2013\end{array}$ & Telefon fotoğrafı & \multirow{5}{*}{$\begin{array}{l}\text { Verdiği İzlenim: Gezi fotoğrafı, kişisel } \\
\text { eşyalar, arkadaşlarla toplu fotoğraf } \\
\text { Yaydığı İzlenim: Gezmeyi, arkadaşlarıyla } \\
\text { vakit geçirmeyi ve sporu sevmektedir } \\
\text { Rol: Kişi kendi eşyalarını başkalarına } \\
\text { sunmayı seven günlük aktivitelerden geri } \\
\text { kalmayan biri olarak göstermektedir } \\
\text { Performans: } 5 \text { fotoğraf paylaşımında } \\
\text { toplam } 437 \text { beğeni, } 19 \text { yorum almısțır } \\
\text { Görünüș: Atletik, fit yapılı, uzun boylu, } \\
\text { esmer } \\
\text { Tutum: Paylaşılan fotoğraflarda pozitif } \\
\text { yaşam tarzı ve atletik vūcut yapısıyla ilgi } \\
\text { çekmek istemiştir }\end{array}$} & 57 & $\cdot$ \\
\hline & $\begin{array}{l}22 \\
\text { Şubat } \\
2013\end{array}$ & $\begin{array}{l}\text { Arkadașlarla } \\
\text { toplu fotoğraf }\end{array}$ & & 67 & 1 \\
\hline & $\begin{array}{l}23 \\
\text { Șubat } \\
2013\end{array}$ & $\begin{array}{l}\text { Dış çekim } \\
\text { manzara }\end{array}$ & & 92 & 8 \\
\hline & $\begin{array}{l}24 \\
\text { Şubat } \\
2013\end{array}$ & $\begin{array}{l}\text { Diş çekim } \\
\text { manzara önünde } \\
\text { üstünde deri } \\
\text { ceket, elinde } \\
\text { çanta }\end{array}$ & & 139 & 9 \\
\hline & $\begin{array}{l}25 \\
\text { Subat } \\
2013\end{array}$ & $\begin{array}{l}\text { Spor salonunda } \\
\text { spor yaparken }\end{array}$ & & 85 & 1 \\
\hline \multirow{5}{*}{ 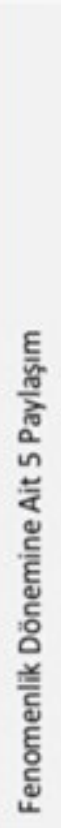 } & $\begin{array}{l}18 \\
\text { Şubat } \\
2019\end{array}$ & $\begin{array}{l}\text { Ünlü restoran } \\
\text { ortamında şarkıcı } \\
\text { arkadaşıla } \\
\text { beraber nargile } \\
\text { içerken fotoğraf. }\end{array}$ & \multirow{5}{*}{$\begin{array}{l}\text { Verdiği İlenim: Takım kıyafetler, ünlü } \\
\text { mekânlar, havalı fotoğraflar } \\
\text { Yaydığı ìlenim: Zengin ünlü oyuncu, } \\
\text { bilindik mekânlarda ünlülerle takılan biri. } \\
\text { Rol: Ünlülerle takılan eğlenceli ortamları } \\
\text { seven zengin biri. Kişi kendisini bekâr, } \\
\text { eğlenceli ortamlarda arkadaşlarıyla vakit } \\
\text { geçirmeyi seven biri olarak sunmaktadır } \\
\text { Performans: } 5 \text { fotoğraf paylaşımında } \\
\text { toplam } 8,344 \text { beğeni, } 158 \text { yorum almıştır } \\
\text { Görünüş: Esmer, uzun boylu, iri yapılı, } \\
\text { karizmatik, saç ve yüz estetiği yaptırmıs,, } \\
\text { son derce bakımlı. } \\
\text { Tutum: Fotoğrafı altına bıraktığı 'bu } \\
\text { arkadaşımla her şey yapılabilir, sırrımı da } \\
\text { paylaşabilirim' yorumundan istediği } \\
\text { arkadaşa sahip olduğunu vurguluyor. Aynı } \\
\text { zamanda bir giyim markasını reklam } \\
\text { etmekle teklif geldiğinde reklam yapmaya } \\
\text { açık olduğunu göstermektedir. }\end{array}$} & 3.907 & 61 \\
\hline & $\begin{array}{l}19 \\
\text { Şubat } \\
2019\end{array}$ & $\begin{array}{l}\text { Restoran } \\
\text { ortamında masa } \\
\text { arkasında oturan } \\
\text { takım elbisede } \\
\text { fotoğraf. }\end{array}$ & & 2.013 & 45 \\
\hline & $\begin{array}{l}24 \\
\text { Subat } \\
2019\end{array}$ & $\begin{array}{l}\text { Dış çekim } \\
\text { fotoğrafı }\end{array}$ & & 765 & 19 \\
\hline & $\begin{array}{l}26 \\
\text { Subat } \\
2019\end{array}$ & $\begin{array}{l}\text { Siyah beyaz takım } \\
\text { elbise üzerinde } \\
\text { çekilen } \\
\text { profesyonel } \\
\text { fotoğraf }\end{array}$ & & 934 & 22 \\
\hline & $\begin{array}{l}28 \\
\text { Subat } \\
2019\end{array}$ & $\begin{array}{l}\text { Marka ayakkabı } \\
\text { ve giyim reklamı } \\
\text { içerikli fotoğraf }\end{array}$ & & 725 & 11 \\
\hline
\end{tabular}

Verdiği İzlenimin Karşılaştırılması: I kullanıcısı sıradan kullanıcıyken sıklıkla sıradan fotoğraflarını paylaşırken fenomen olduktan sonra paylaşım aralığı uzamaya başlamış. İlk başlarda kişisel eşyalarını, günlük aktivitelerini takipçileriyle paylaşsa da fenomen olduktan sonra profesyonel fotoğraf çekimlerine ağırlık vermiş. Güncel postları genelde ünlü mekânlarda çekilen fotoğraflar, reklam tanıtım içerikli paylaşımları kapsamaktadır. 
Yaydı̆̆g İzlenimin Karşılaştırılması: İlk başlarda I kişisi sıradan kullanıcı olduğu dönemlerde aktivitelerinden geri kalmayan maddi durumu normal bir kişi izleniminde bulunmuş. Fakat son paylaşımlarında genelde havalı (cool) takılan, bilindik mekânlarda seçkin kişilerle vakit geçirmeyi seven, zengin, ünlü oyuncu izlenimini yaymaktadır.

Rollerin Karşılaştırılması: Instagram'ı kullanmaya başladığında paylaştığı eski postlarıyla son paylaşımlarını kıyaslandığında I kullanıcısının rolünün sıradan birinden zengin birine doğru değiştiğini görebiliriz. Bu kullanıcı artık profesyonel çekilen fotoğraflarını paylaşmaktadır. Kendisini sanat camiasının ünlü isimlerinden biri olarak tanıtmaktadır.

Performans Karşılaştırması: İlk döneme ait 5 fotoğrafta toplam 437 beğeni, 19 yorum, son döneme ait 5 fotoğraf paylaşımında ise toplam 8,344 beğeni, 158 yorum almıştır.

Kişisel Vitrinin / Görünüşün Karşılaştırılması: I kişisinin görünüşündeki değişim sıradan kullanıcı olduğu dönemlerdeki postları ile güncel paylaşımları arasındaki içeriklerde fark edilmektedir. I kullanıcısı yüz ve saç estetiği yaptırmış, fotoğraflarında son derece bakımlı olmaya özen göstermektedir. Genelde artık takım kıyafetlere üstünlük vermektedir. Bulunduğu bilindik mekânlar, ünlü insanlarla vakit geçirmesini görüntülemesi ve profesyonel çekilmiş fotoğraflar, I kişisinin havalı görünmesini istemesine yönelik paylaşımlar olduğunu göstermektedir. Aynı zamanda profilinde yaptığı ürün veya marka kıyafet tanıtımlarından reklam tekliflerine açık biri olduğunu sunmaktadır. 


\subsubsection{Kullanıcı F'nin Analizi}

Tablo 9: Kullanıcı F'ye Ait Instagram Profili İstatistiksel Verileri
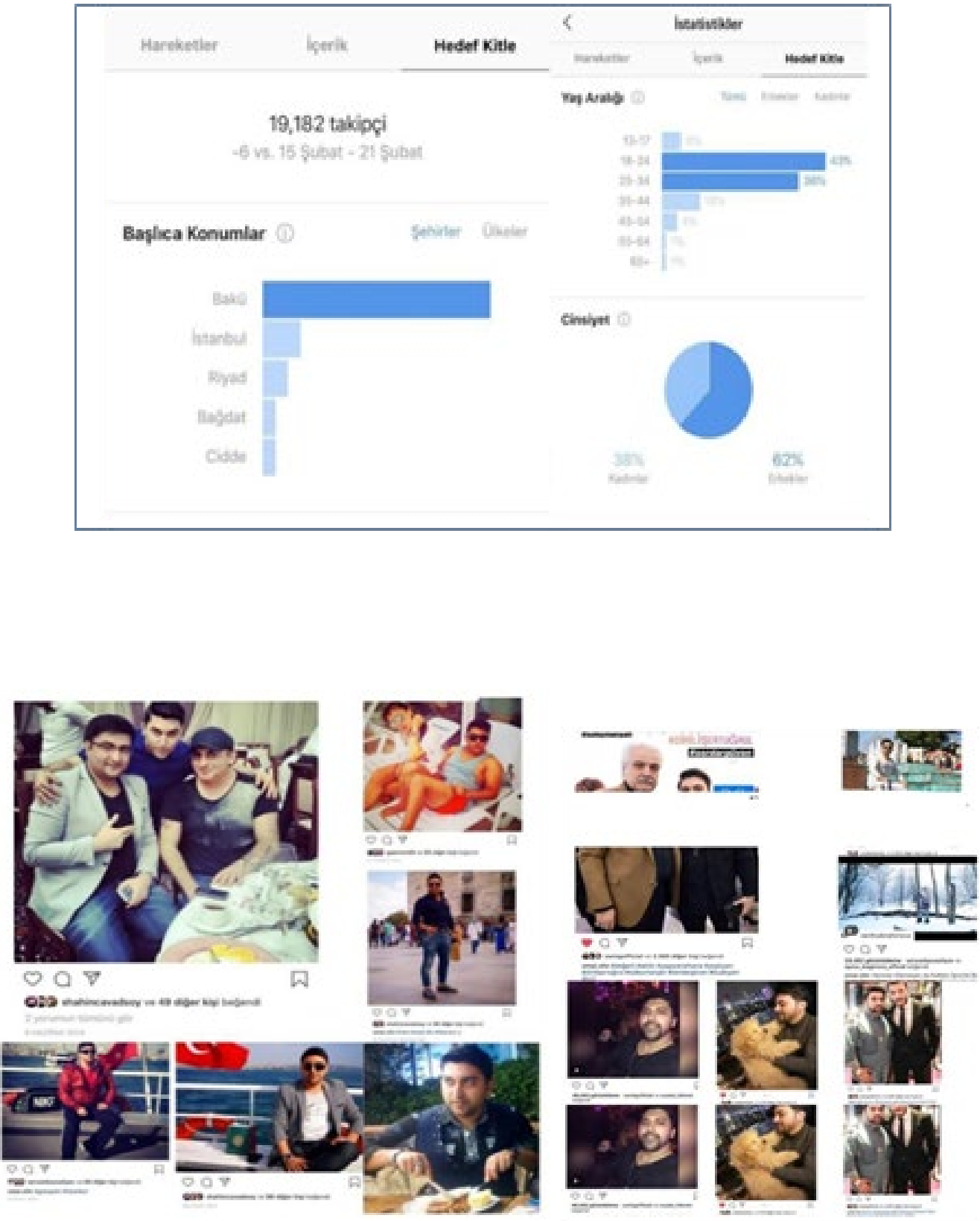

Görsel 5: Kullanıcı F'nin Fenomenlik Öncesi ve Sonraki Döneme Ait 5 Paylaşımı 
Tablo 10: : F Kullanıcısının Fenomenlik Öncesi Döneme ve Fenomenlik Dönemine Ait Paylaşımlarının Dramaturjik Analizi

\begin{tabular}{|c|c|c|c|c|c|}
\hline \multicolumn{6}{|c|}{ INST } \\
\hline \multicolumn{6}{|c|}{ Kullanıcı (Aktör) Adı: I Kullanıcısı } \\
\hline № & Tarih & Fotoğraf içeriği & İçerik Analizi & $\begin{array}{l}\text { Beğeni } \\
\text { Sayısı }\end{array}$ & $\begin{array}{l}\text { Yorum } \\
\text { Sayisı }\end{array}$ \\
\hline \multirow{5}{*}{ 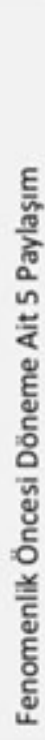 } & $\begin{array}{l}9 \\
\text { Haziran } \\
2014\end{array}$ & $\begin{array}{l}\text { Iç Mekân: Arkadaşlarla } \\
\text { restoranda çekilen } \\
\text { fotoğraf }\end{array}$ & $\begin{array}{l}\text { Verdiği İlenim: Gezi ve tatil } \\
\text { fotoğraflan, kișisel eşyalar. } \\
\text { Yaydığı İlenim: Gezmeyi ve tatil }\end{array}$ & 49 & 2 \\
\hline & $\begin{array}{l}20 \\
\text { Temmuz } \\
2014\end{array}$ & $\begin{array}{l}\text { Dış mekan: Bir arkadaş } \\
\text { ve elde telefonla } \\
\text { çekilmiş fotoğraf. }\end{array}$ & $\begin{array}{l}\text { geçirmeyi seven bekâr biri. } \\
\text { Rol: Tatil ve diğer aktivitelerini }\end{array}$ & 69 & - \\
\hline & $\begin{array}{l}20 \text { Eylūl } \\
2014\end{array}$ & $\begin{array}{l}\text { Dış mekan: Yeni } \\
\text { kıyafetler, elde cüzdan } \\
\text { ve poşetlerle Cami } \\
\text { önünde çekilen fotoğraf }\end{array}$ & $\begin{array}{l}\text { görūnmektedir. Özel fotoğraflarını } \\
\text { takipçilerine sunmakta. } \\
\text { Performans: } 5 \text { fotoğraf }\end{array}$ & 94 & 5 \\
\hline & $\begin{array}{l}27 \text { Eylü } \\
2014\end{array}$ & $\begin{array}{l}\text { Dış mekan: Gözlük ve } \\
\text { markalı çanta ön planda } \\
\text { vapurda çekilmiş } \\
\text { fotoğraf }\end{array}$ & $\begin{array}{l}\text { yorum almıştır. } \\
\text { Kişisel Vitrin / Görünüş: Kısa boylu, } \\
\text { beyaz tenli. }\end{array}$ & 88 & - \\
\hline & $\begin{array}{l}28 \text { Eylül } \\
2014\end{array}$ & $\begin{array}{l}\text { Dış mekan: Deniz } \\
\text { kıyısında, aksesuarların } \\
\text { ön planda olduğu } \\
\text { fotoğraf }\end{array}$ & $\begin{array}{l}\text { gūnaydın İstanbul' yorumuyla } \\
\text { anlașılıyor ki, görünmeyi, kendi } \\
\text { gōrünümüyle dikkat çekmeyi ve } \\
\text { eşyalarını sunmayı hedeflemektedir. }\end{array}$ & 97 & - \\
\hline \multirow{5}{*}{ 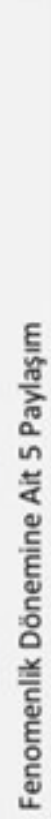 } & $\begin{array}{l}6 \text { Mart } \\
2019\end{array}$ & $\begin{array}{l}\text { Dış mekan: Ünlū biriyle } \\
\text { meşhur bir meydanda } \\
\text { cekilmis fotoŏraf }\end{array}$ & $\begin{array}{l}\text { Verdiği ízlenim: Ünlü kişilerle } \\
\text { beraber fotoğraf, kişisel fotoğrafları, } \\
\text { bilinen mekânlar, kişisel esyalar. }\end{array}$ & 2.385 & 3 \\
\hline & $\begin{array}{l}9 \text { Mart } \\
2019\end{array}$ & $\begin{array}{l}\text { Dış mekan: Meşhur bir } \\
\text { meydan altın kolye ve } \\
\text { saat, marka çantanın ön } \\
\text { planda olduğu bir } \\
\text { fotoğraf }\end{array}$ & $\begin{array}{l}\text { Yaydığı İzlenim: Bu kişinin profilinde } \\
\text { son fotoğraflarına bakıldığında } \\
\text { ünlülerle ortak projeler yapan zengin } \\
\text { bir menajer izlenimi yaydığı belli } \\
\text { olmaktadır. }\end{array}$ & 2.220 & 5 \\
\hline & $\begin{array}{l}11 \text { Mart } \\
2019\end{array}$ & $\begin{array}{l}\text { Video: Unlülerin } \\
\text { takıldığı bir mekânda } \\
\text { doğum günü öz çekimi }\end{array}$ & $\begin{array}{l}\text { Rol: Yogun bir menajer. Genellikle } \\
\text { eğlenceli mekanlarda, aksesuarların } \\
\text { öne çıktığı havalı paylaşımlar. }\end{array}$ & 49.223 & 31 \\
\hline & $\begin{array}{l}12 \text { Mart } \\
2019\end{array}$ & $\begin{array}{l}\text { Şarkıcı bir arkadaşın } \\
\text { yeni klipi ile "hayırlı } \\
\text { olsun" mesajlı video }\end{array}$ & $\begin{array}{l}\text { Performans: Toplam 89,150 beğeni, } \\
44 \text { yorum. } \\
\text { Kişisel Vitrin / Görünüș: Dudak, }\end{array}$ & 33.259 & 1 \\
\hline & $\begin{array}{l}15 \text { Mart } \\
2019\end{array}$ & $\begin{array}{l}\text { Boynunda altın } \\
\text { kolyeler, elinde cins } \\
\text { köpek ile ünlü bir } \\
\text { mekânda fotoğraf }\end{array}$ & $\begin{array}{l}\text { burun ve yūz estetiği yaptırmış, } \\
\text { bakımlı, fönlū saçlı } \\
\text { Tutum: Beğenilme arzusu. Kendisini } \\
\text { ve kullandığı eşyaları sergilemekten } \\
\text { zevk alma. Narsist duygular. Havalı } \\
\text { ve etkilemeye yōnelik, ün kazanma } \\
\text { beklentisi. }\end{array}$ & 2.063 & 4 \\
\hline
\end{tabular}

Verdiği İzlenimin Karşılaştırılması: F kişisi sıradan kullanıcıyken verdiği izlenimleri ile fenomen olduktan sonra verdiği izlenimlerinin içerikleri çoğu kez aynı tarz olsa da değişim, mekanların ve sergilediği eşyaların kalite düzeyinin artmasında belli olmaktadır. F kullanıcı daha önce dış mekânlarda fotoğraf yayınlarken, güncel paylaşımlarında bilindik ünlü mekânları tercih 
etmektedir. İlk başlarda kullandığı sıradan kişisel eşyaları marka firmaların ürünleriyle değişim göstermiştir.

Yaydığı İzlenimlerin Karşılaştırılması: İlk başlarda günlük aktivitelerini paylaşan sıradan bir kişi izlenimi yayan F kullanıcısı, takipçi sayısı yükseldikçe ünlülerle ortak projelerde çalışan zengin bir menajer imajı yaymaktadır. Kullandığı değerli aksesuarlar, marka cüzdanlar, çantalar, kıyafetler F kişisinin ekonomi durumunun iyi olduğu izlenimini göstermektedir.

Rollerin Karşılaştırılması: F kullanıcı Instagram'ı ilk kullandığı zamanlarda kendisini boş zamanlarında arkadaşlarıyla vakit geçirmeyi, gezmeyi, tatil yapmayı seven, günlük aktivitelerini takipçileriyle paylaşan biri olarak tanımlamaktadır. Fakat güncel paylaşımlarında genellikle ün kazanmış, bilindik ortamlarda takılan sürekli farklı projelerde çalışan zengin menajer olarak sunmaktadır. Bu durumda F kişisinin sıradan bir genç rolünden kendi alanında başarılı menajer olarak değişim göstermiştir.

Performans Karşılaştırması: İlk dönemlerde F kullanıcının performansı 5 fotoğraf paylaşım sonucunda toplam 397 beğeni, 7 yorumla sinırliyken son güncel 3 fotoğraf, 2 video paylaşımından toplam 89,15 beğeni, 44 yorum sayısına yükselmiştir.

Kişisel Vitrinin / Görünüşün Karşılaştırılması: F kişisinin sıradan kullanıcı olduğu dönemlerde paylaştığı fotoğrafları ile güncel son paylaşımları karşılaştırıldığın da görünüşü arasındaki değişim belirli şekilde fark edilmektedir. Son paylaşımlarında burun, dudak, yüz estetiği yapıldığı açıkça görünmektedir. Aynı şekilde F kişisinin kullandığı eşyaların ve mekânların kalite düzeyi artmıştır. 


\subsubsection{Kullanıcı G'nin Analizi}

27 yaşındaki erkek G kullanıcısı, oyunculuk yapmaktadır. 2013 yılından beri Instagram kullanan, filmlerle ilgili paylaşımlar yapan, 135 bin takipçisi olan bir Instagram fenomenidir.

Tablo 11: Kullanıcı G'ye Ait Instagram Profili İstatistiksel Verileri
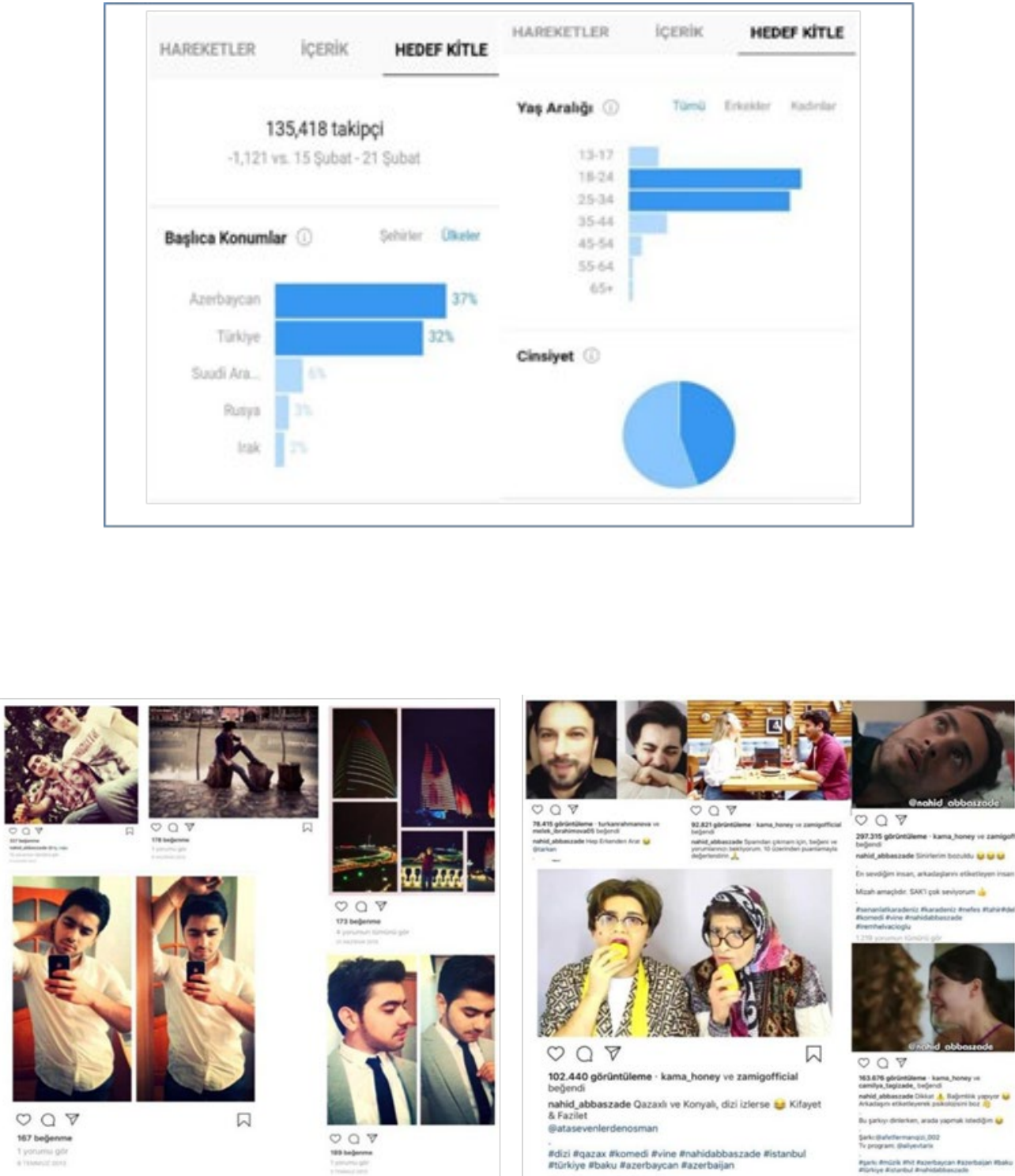

Görsel 6: Kullanıcı G’nin Fenomenlik Öncesi Ve Sonraki Döneme Ait 5 Paylaşımı 
Tablo 12: Kullanıcı G'nin Fenomenlik Dönemine Ait Paylaşımlarının Dramaturjik Analizi

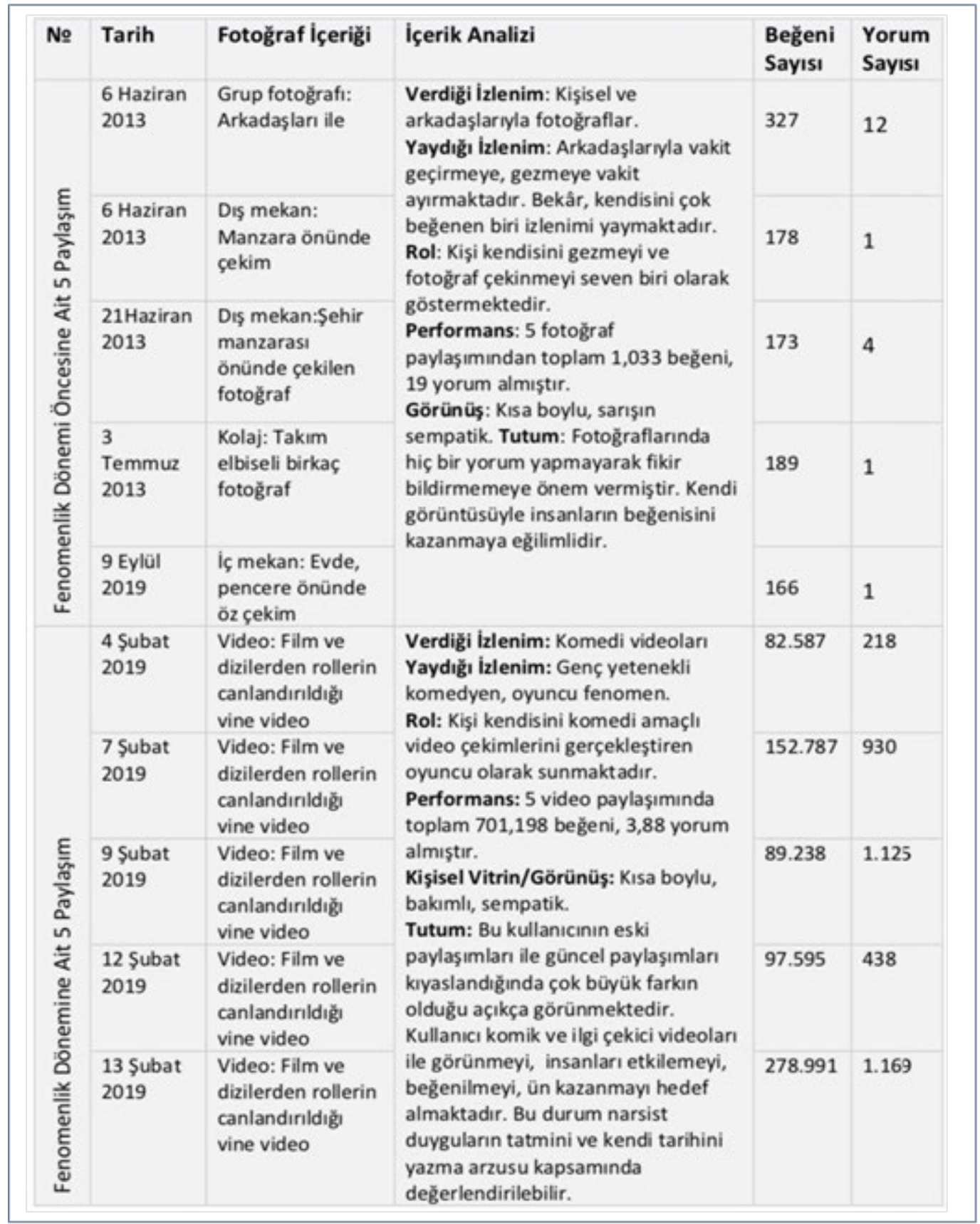

Verdiğ İZlenimin Karşılaştırılması: G kişi Instagram'da fenomenlik öncesi dönemde arkadaşıyla beraber, gezi, öz çekim fotoğraflarını sunmayı tercih ettiği, buna karşın fenomenlik döneminde daha çok beğeni ve yorum aldığı videoları düzenlemeye başladığı görülmektedir. $\mathrm{Bu}$ durum kullanıcının paylaşımlarını tamamen takipçileri için düzenlediğini şeklinde yorumlanabilir.

Yaydığı İzlenimin Karşılaştırılması: Fenomenlik öncesi dönemde G kullanıcısı, kişisel fotoğraflarında kendini seven, arkadaşıyla vakit geçiren izlenimi yaymakta, buna karşın fenomenlik döneminde takipçileri tarafından ilgi gören, sevilen hatta takipçilerini güldürmeyi 
amaçlayan videolar paylaştığı görülmektedir. Rol Karşılaştırması: G kullanıcısı, fenomenlik öncesi dönemde kendisini sıradan bir genç gibi tanımlamakta, buna karşın fenomenlik döneminde, takipçi sayısı arttıkça genelde dizi ve filmlerden fragmanlar hazırlayan ve kurgulayan bir oyuncu fenomen olarak sunduğu görülmektedir.

Performans Karşılaştırması: G kullanıcısı, fenomenlik öncesi ile fenomenlik dönemi arasında performans açısından büyük bir farkın ortaya çıtı̆̆ı görülmektedir. Kişi kurguladığ paylaşımlarla ün kazanmış görünmektedir.

Kişisel Vitrin / Görünüş Karşılaştırması: G kullanıcısının görünüşü, fenomenlik öncesi dönemde sabit bir şekilde görünmekte, buna karşın fenomenlik döneminde ise rolden role girdiği gözlenmektedir. Genellikle oynayacağı role uygun tarzda giyimleri tercih etmektedir. Ayrıca komik videolar hazırlayarak daha fazla takipçi kazanmayı hedeflediği izlenimi vermektedir. Daha çok etkileşim almak için giderek daha profesyonel şekilde videolarını kurgulamaktadır.

\section{SONUÇ}

Goffman'ın kuram ve yöntemi sosyal paylaşım ağı Instagram örneklerimiz üzerinde önemli veriler elde etmemizi sağlamıştır. Sosyal medyada da günlük hayatta olduğu gibi başkalarının zihninde kendisiyle ilgili nasıl izlenim bırakmak istiyorsa kullanıcı, imajını da o yönden yönetmeye çalışmaktadır. Sanal ortamda kurulan profillerin çoğunluğu maalesef araştırma sürecinde yaptığımız sözlü mülakat zamanı karşılaştığımız kişilerle aynı değildir. Üzerinde gözlerin olduğunun farkında olan bireyler takipçilerini etkilemek onların onay ve beğenilerini almak için gerçek hayatlarından farklı bir benlik sunarak kendilerini kaybetmekte, sanal dünyanın cazibesine kapılmaktadır.

Araştırma zamanı kullanıcıların fenomen olmadıkları dönemlerde ve sonrasındaki güncel paylaşımlarında içerikleri giderek farklı, orijinal ve ilgi çekici olması yönünde değişim göstermektedir. Tweenge, 'Ben Nesli' adlı kitabında bugünün gençlerinde bahsederken “ben nesli'nin çoğu, bir gün ünlü olabilme beklentisindedirler" der (Twenge, 2009, s. 123). Etkileşim oranı ve yoğunluğu fazla olan sosyal medyanın dünya çapında yaygınlaşması şöhret kültürünü artırmaya başlamıştır. Sosyal medyada aktif olan ve tanımadıkları kişileri kabul ederek kendisine hayran kitlesi oluşturan bu kullanıcılar aynı zamanda kendi arzusu ile başkaları tarafından izlenmeye izin vermektedir. Bu bağlamda Goffman'ın günlük hayatta benlik sunumunda temel aldığı gözlemci etkisi sonucunda kazandığı etkileşim sosyal medyada bireyin davranışları üzerinde öz etkisini göstermektedir. Bu yönde İnternet teknolojisinin insana sınırsız bir özgürlük ve kendini ifade etme biçimleri sunmasıyla kişinin kendisini olduğu gibi değil de olmak istediği gibi sunmasına olanaklar sağlamıştır. Söz konusu kullanıcı kendi doğal benliğinden ziyade ideal benliğini sunma çabasında davranışlar sergilemeye başlamıştır. Bireyin sosyal medyada paylaşımları sonucunda takipçileri tarafından aldığı beğeni, yorum sayısı ve takipçi isteği, başkaları tarafından onaylanan, takdir 
edilen davranışların sergilenmesine yol açmaktadır. Her iki duruma, 4 kullanıının profil analizinde de rastlanmıştır.

Yapılan araştırma sonuçuna göre takipçi sayısı daha fazla olan kullanıcılar bir gönderiyi paylaşmadan önce takipçilerinin düşünce ve tepkilerini fazlaca önemsiyorlar. Bu durumda kişi daha önceki paylaşımlarından aldığı geri bildirimlere yönelik içeriklerini başkalarının ideallerine göre biçimlemektedir. Etkileşim (yorum, beğeni, takipçi isteği vb.) arttıkça kullanıcı daha fazla kaygılanmakta, benlik sunumuna özen göstermekte ve davranışlarına yön vermektedir. Dolayısı ile sosyal medyada yaratılan kimliğe uygun sergilenen idealize edilmiş benliklerin bireyin normal hayatta sahip olduğu öz doğal benliği arasındaki farkın büyümesi sonucunda gelecek yaşamında depresif ve kaygı duymasına neden olabilmektedir.

\section{KAYNAKÇA}

Atay, T. (2017). Görünüyorum O Halde Varım: Meşhuriyyet Çağında Kültür ve İnsan. İstanbul: Can Yayınları. Bakıroğlu, C. T. (2018). Sosyalleşme ve Kimlik İnşası Ekseninde Sosyal Paylaşım Ağları. İstanbul.

Baudrillard, J. (1997). Tüketim Toplumu. İstanbul: Ayrıntı Yayınları.

Baumeister, D. M. (1984). Role of self-presentation and choice in cognitive dissonance under forced compliance: Necessary or sufficient causes? Journal of Personality and Social Psychology içinde, 46, $5-13$.

Baymur, F. (1989). Genel Psikoloji. İstanbul: İnkilap Kitapevi.

Brehm, K. V. (1990). Social Psychology. Boston: Houghton Mifflin.

Castells, M. (2002). Gerçek Sanallık Kültürü. İstanbul: Cogito yayınları.

Cooley, H. C. (1962). Social Organization. New York: Schocken.

Coser, L. A. (2008). Marsters of sociological thought ideas in historical and social context. Sosyolojik Düşüncenin Ustaları: Tarihsel ve Toplumsal Bağlamlarında Fikirler. İstanbul: De Ki Basım Yayın Ltd. Şti.

Coser, L. A. (2010). Sosyolojik Düşüncenin Ustaları. Ankara: Basım Yayın.

Ergun, D. (1973). Sosyoloji El Kitabı. Ankara: Gerçek Yayınevi.

Goffman, E. (2016). Günlük Yaşamda Benliğin Sunumu (2. Baskı b. Ç. Gezer, Çev.) İstanbul: Metis Yayınları.

Gönenç, Ö. (1993). İletişimin Tarihi. İstanbul: İstanbul Üniversitesi İletişim Fakültesi.

Hood, B. (2014). The Self Illusion - Benlik Yanılsaması (1. Baskı b.; E. Özdemir, Çev.) İstanbul: Ayrıntı Yayınları.

Işıklı, Ş. (2012). Kuantum Felsefesi: Postmodern Bilimin Doğuşu. Ankara: Birleşik Basım Yayın. 
Işıklı, Ş. ve Küçükvardar, M. (2016). Bilişim Devrimi: Teknolojinin Felsefi ve Sosyolojik Analizi. Ankara: Birleşik Basım Yayım.

Kinch, J. (1963). A formalized theory of the self concept . American Journal of Sociology, 481.

Köknel, Ö. (1986). Insanı Anlamak. İstanbul: Altın Kitaplar Yayınev.

Lyon, B. vd. (2013). Akışkan Gözetim. İstanbul: Ayrıntı Yayınları.

Marshall, G. (2009). Sosyoloji Sözlü̆ğ̈. Ankara: Bilim ve Sanat Yayınları.

McLuhan, M. (1964), Understanding Media : The Extensions of Man, Canada: McGraw Hill.

Özer, O. (1977). Toplumbilime Giriş. Ankara: S.B.F Yayınları.

Salomon, D. (2013). Moving on from Facebook using Instagram to connect with undergraduates and engage in teaching and learning. ACRL TechConnect, 410.

Sennett, R. (2012). Beraber. (1. Baskı b.; İ. Özküralpli, Çev.) İstanbul: Ayrıntı.

Stefanone, M. (2010). The relationship between traditional mass media and social media: Reality television as a model for social network. Journal of Broadcasting and Electronic Media(3), 508-52.

Tajfel, H. T. (1996). The social identity theory of intergroup behavior. Worchel ve Austin (Eds.), Psychology of Intergroup Relations içinde. Chicago: Psycology of Intergroup Relations.

Tonbay, İ. (2019). Sosyal Olmak (s. 90). içinde Ankara: Sabev Yayınları.

Twenge, J. (2009). Ben Nesli. (1. Basım b.; E. Öztürk, Çev.). İstanbul: Kaknüs Yayınları.

Yağlı, S. (2006). Gündelik hayatımızda akıl tutulması: medya uygulamalarında tüketim ideolojisinin izlerini sürmek. Gündelik Hayat ve Medya Tüketim Kültürü içinde. Ankara : Ebabil Yayınları.

Young, D. (2009). The Mirror Effect. New York: HarperCollins. 